\title{
EVALUATION OF ANTIMICROBIAL ACTIVITY AND TOXIC POTENTIAL OF EXTRACTS AND TRITERPENES ISOLATED FROM Maytenus imbricata
}

Vanessa G. Rodrigues*, Lucienir P. Duarte, Grácia D. F. Silva, Fernando C. Silva, Jefferson V. Góes, Jacqueline A. Takahashi e Lúcia P. S. Pimenta

Departamento de Química, Instituto de Ciências Exatas, Universidade Federal de Minas Gerais, Av. Antônio Carlos, 6627, 31270-901 Belo Horizonte - MG, Brasil

Sidney A. Vieira Filho

Departamento de Farmácia, Escola de Farmácia, Universidade Federal de Ouro Preto, Rua Costa Sena, 171, 35400-000 Ouro Preto - MG, Brasil

Recebido em 3/10/11; aceito em 26/2/12; publicado na web em 2/7/12

\begin{abstract}
The phytochemical study of hexane/ethyl ether (1:1) extract of the roots of M. imbricata, Celastraceae, resulted in the isolation and characterization of six known triterpenes: $11 \alpha$-hydroxylup-20(29)-en-3-one, previously isolated from this species besides, $3 \beta, 11 \alpha-$ di-hydroxylup-20(29)-ene, 3,7-dioxofriedelane, 3-oxo-29-hydroxyfriedelane, tingenone and 6-oxo-tingenol. The chemical structures of these triterpenes were established by spectrometric data (IR, ${ }^{1} \mathrm{H}$ and $\left.{ }^{13} \mathrm{C} \mathrm{NMR}\right)$ and through comparison with literature data. The hexane/ethyl ether (1:1), ethyl acetate and methanol extracts, and 11 $\alpha$-hydroxylup-20(29)-en-3-one, tingenone and 6-oxo-tingenol,

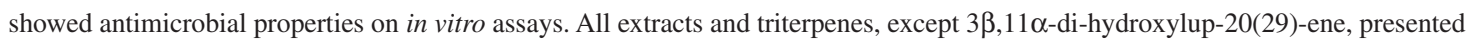
toxicity demonstrated by the larvicidal effect test using Artemia salina.
\end{abstract}

Keywords: Maytenus imbricata; Celastraceae; pentacyclic triterpenes.

\section{INTRODUCTION}

From different species of the genus Maytenus, various groups of secondary metabolites have been found, such as triterpenes, ${ }^{1}$ sesquiterpenes, ${ }^{2}$ phenolic glycosides, ${ }^{3}$ alkaloids, ${ }^{1}$ flavonoids,${ }^{4,5}$ and tannins,${ }^{5}$ among others. Members of this genus are important not only in terms of experimentally observed biological activities, ${ }^{6}$ but also because they are used in folk medicine for gastric diseases, ${ }^{7}$ and as antiseptic, anti-asthmatic, anti-tumor, ${ }^{8}$ antiviral, ${ }^{9}$ and anti-inflammatory agents. ${ }^{10}$ In a recent review, Niero et al. ${ }^{11}$ provided an adequate description of the ethnopharmacological, chemical and pharmacological knowledge about species of the genera Maytenus, with particular emphasis on those growing in Brazil. Many species of this genus are effective medicines, and represent promising sources of bioactive substances of medicinal interest.

The indiscriminate use of antibiotics has induced an increase in the incidence of infectious diseases caused by pathogenic microorganisms that have acquired resistance to several antibiotics currently used in clinical treatments. This scenario has led to a continuous, urgent search for new antimicrobial compounds, especially those bearing different chemical structures and having specific mechanisms of action. ${ }^{12}$ In this context, the compounds isolated from plants have emerged as a promising alternative. Indeed, around 50\% of drugs approved by the Food and Drug Administration (FDA) between 1981 and 2006 were of natural origin. ${ }^{13}$

It has been reported that the molecular diversity of natural products is higher than those derived from chemical synthesis processes. Thus, the biological assays of natural products represent a continuing source of new structural models for compounds with antimicrobial properties and are an important alternative for reducing the incidence of infectious diseases. ${ }^{14}$

According to the literature, compounds that present brine shrimp (Artemia salina) toxicity, in general also have cytotoxic properties

*e-mail: vanessa.greg@yahoo.com against cells of solid tumors found in humans. This bioassay has being considered as adequate for initial screening of bioactive molecules, paving the way for subsequent tests of greater complexity such as Aedes aegypti larvicidal assays or for testing the response of cancer cells to anti-cancer drugs. ${ }^{15}$

Maytenus imbricata Mart, ex. Reissek is a shrub or subshrubs found in Cerrado regions (rupestrian fields) of Minas Gerais and Bahia States, Brazil. Leaves, twigs and stems of this species were subjected to biological assays. The $\mathrm{CHCl}_{3}$, EtOAc and EtOH extracts of leaves, the hydroalcoholic extract of roots, the EtOAc extract of stems and epicatechin, isolated from $M$. imbricata showed antioxidant activity. The 3,4-seco-friedelan-3-oic acid, isolated from leaves, presented inhibitory activity of ATP synthesis raising possibilities for its potential use in the future development of natural herbicides. ${ }^{16}$

In this paper, the phytochemical study of the roots of Maytenus imbricata and isolation of the pentacyclic triterpenes (PCTT) $11 \alpha$-hydroxylup-20(29)-en-3-one (1), 3 $\beta, 11 \alpha$-di-hydroxylup-20(29)ene (2), 3,7-dioxofriedelane (3), 3-oxo-29-hydroxyfriedelane (4), tingenone (5) and 6-oxo-tingenol (6) (Figure 1) were reported.

The extracts, and some constituents from roots, of $M$. imbricata were submitted to in vitro antimicrobial assays to evaluate their properties against the bacteria Staphylococcus aureus, Bacillus cereus, Salmonella typhimurium, Escherichia coli and the fungus Candida albicans. The cytotoxic effect of these constituents was screened through their larvicidal effect on Artemia salina.

\section{EXPERIMENTAL}

\section{Plant material}

Roots of Maytenus imbricata (Celastraceae) were carefully collected so as to prevent damage to the specimen. The collection area is located on Morro de Santana, Ouro Preto municipality, Minas Gerais, Brazil. The plant material was identified by the botanists Dr. R. M. de C. Okano, Departamento de Botânica of the Universidade 

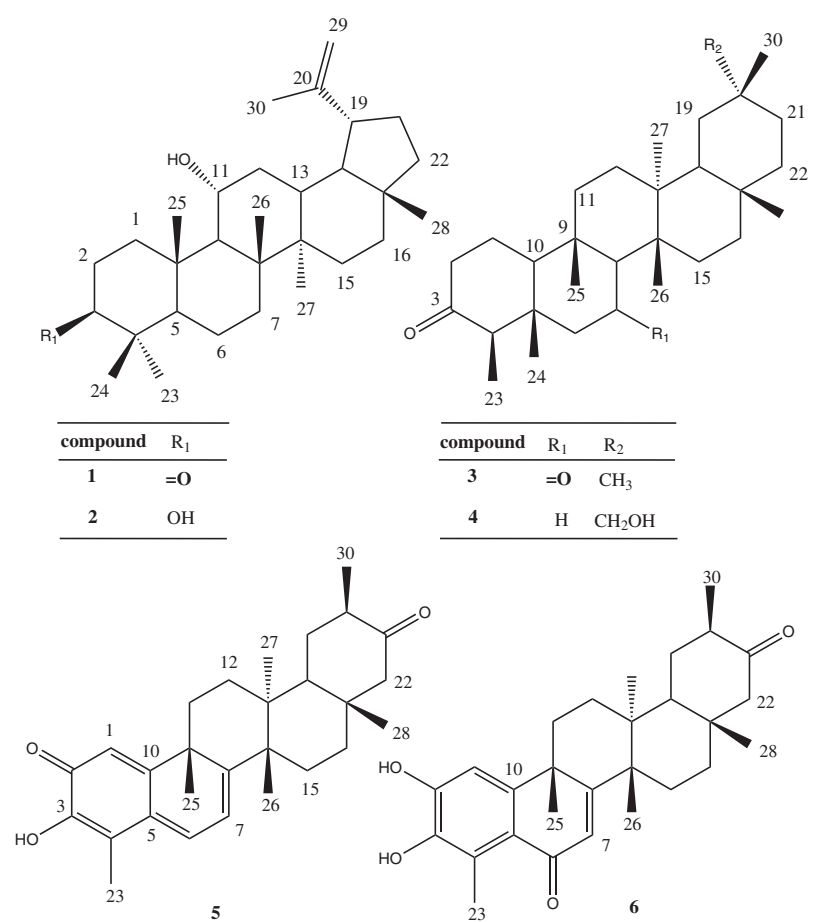

Figure 1. Chemical structures of pentacyclic triterpenes isolated from roots of Maytenus imbricata

Federal de Viçosa (UFV) and M. C. T B. Messias, Departamento de Botânica of the Universidade Federal de Ouro Preto (UFOP). A voucher specimen ( $\mathrm{N}^{\circ}$ 27780) was deposited in the collection of the Herbarium of Departamento de Botânica, UFV, Brazil.

\section{General procedures}

Purification processes by column chromatography (CC) were carried out using silica gel $60(0.063-0.200 \mathrm{~mm})$ as the stationary phase. Organic solvents or mixtures of increasing polarity were used as mobile phases. Silica gel 60 GF (Merck) was used to perform analytical [(TLC), $0.25 \mathrm{~mm}$ ] or preparative [(PTLC), $0.75 \mathrm{~mm}$ ] thin layer chromatographic processes.

The ${ }^{1} \mathrm{H}(400$ or $200 \mathrm{MHz})$ and ${ }^{13} \mathrm{C}\left(100\right.$ or $\left.50 \mathrm{MHz}_{3}\right) \mathrm{NMR}$ spectra were obtained on a Bruker Avance DRX-400 or DPX-200 spectrometer, operating at $300 \mathrm{~K}$. The chemical shifts $(\delta)$ were expressed in units of ppm, using TMS as a reference $\left(\delta_{H}=\delta_{C}=0\right)$ and the coupling constants $(J)$ were expressed in $\mathrm{Hz}$. $\mathrm{CDCl}_{3}$ was used as the solvent for the samples.

The IR spectra of constituents in $\mathrm{KBr}$ discs were obtained on a Shimadzu IR408 spectrometer and the results reported in reciprocal centimeters $\left(\mathrm{cm}^{-1}\right)$ in the range $400-4000 \mathrm{~cm}^{-1}$.

The melting point $(\mathrm{mp})$ ranges were determined on an MQAPF-302 apparatus (Microquímica Equipamentos Ltda, Brazil).

\section{Extraction and isolation of compounds}

The collected roots of $M$. imbricata were powdered in a mill. The powder $(1.5 \mathrm{~kg})$ was then submitted to extractions in a Soxhlet apparatus with hexane-ethyl ether (1:1), ethyl acetate, and finally with methanol. During extraction with hexane/ethyl ether (1:1) a solid was formed and separated by filtration giving the hexane/ethyl ether solid material [HES (22.2 g)]. The solvent of the filtrated product was removed in a rotatory evaporator, giving the hexane/ethyl ether $(1: 1)$ extract [HEE $(16.1 \mathrm{~g})$ ]. During extraction using ethyl acetate, another solid was formed and separated by filtration, giving the ethyl acetate solid [EAS (56.2 g)]. The resultant product of solvent removal was ethyl acetate extract [EAE (21.2 g)]. Finally, the methanol extract [ME (176.7 g)] was obtained. A total of $2 \mathrm{~L}$ of hexane/ethyl ether (1:1), $2 \mathrm{~L}$ of ethyl acetate and $2 \mathrm{~L}$ of methanol were used in the extraction processes.

The extract HEE (3.0 g) was submitted to silica gel (300.8 g) $\mathrm{CC}$ eluted with hexane-EtOAc. Three hundred fifty fractions of 100 $\mathrm{mL}$ each were obtained and grouped according to the similar profiles observed in the chromatoplates. Fractions 14 to 19 produced a white crystalline solid $(12.3 \mathrm{mg}), 0.41 \%$ yield and $\mathrm{mp} 247.7-250.1^{\circ} \mathrm{C}$. This solid was identified as 3,7-dioxo-friedelane (3). The fractions 44-49 provided a white solid in the form of flakes $(63.1 \mathrm{mg}), 2.10 \%$ yield, mp 154.2-158.8 ${ }^{\circ} \mathrm{C}$, subsequently identified as $11 \alpha$-hydroxylup20(29)-en-3-one (1). Fractions 84-95 produced a white crystalline solid (7.0 mg), $0.23 \%$ yield, $\mathrm{mp} 146.9-148.4{ }^{\circ} \mathrm{C}$ which was identified as 3-oxo-29-hydroxyfriedelane (4). Fractions 107-128 produced an amorphous orange solid $(183.3 \mathrm{mg})$ which was subjected to silica gel CC eluted with $\mathrm{Hex}, \mathrm{EtOAc}$ and $\mathrm{MeOH}$, pure or in mixtures of increasing polarity, providing 240 fractions of $10 \mathrm{~mL}$ each. Solvent evaporation from fractions 211 to 235 (eluted with Hex/EtOAc 6:4) produced an orange solid $(64.4 \mathrm{mg}), 2.15 \%$ yield, $\mathrm{mp} 145.0-147.9^{\circ} \mathrm{C}$, which was identified as tingenone (5).

Fractions 205-207 produced an amorphous orange solid (146.7 $\mathrm{mg}$ ) which was submitted to silica gel CC (47.3 mg) eluted with $\mathrm{Hex}, \mathrm{EtOAc}$ and $\mathrm{MeOH}$, pure or in mixtures of increasing polarity, providing 137 fractions of $10 \mathrm{~mL}$ each. After the solvent was withdrawn, fractions 1 to 15 (eluted with Hex/EtOAc 9:1) yielded an orange solid $(25.3 \mathrm{mg})$, which showed three spots when analyzed by TLC. These fractions (1-15) were submitted to silica gel PTLC eluted with Hex/EtOAc 7:3. The less polar compound $(\mathrm{Rf} \sim 0.9)$ was isolated as a white solid (11.0 mg), 0.37\% yield, mp 212.9$218.6{ }^{\circ} \mathrm{C}$ and was identified as $3 \beta, 11 \alpha$-di-hydroxylup-20(29)-ene (2). Fraction 76 yielded a light yellow solid $(8.0 \mathrm{mg}), 0.27 \%$ yield, mp $218.7-221.4{ }^{\circ} \mathrm{C}$ that was identified as 6-oxo-tingenol (6). These terpenes were characterized through their NMR spectral data and also by comparing with published data.

The extract HES (2.0 g) was submitted to silica gel (107.9 g) CC eluted with $\mathrm{Hex}$, EtOAc and $\mathrm{MeOH}$, pure or in mixtures of increasing polarity, providing 114 fractions of $25 \mathrm{~mL}$ each that were grouped according to the similar profiles observed in the chromatoplates.

Fractions 33-42 produced an amorphous brown solid (55.0 mg) which was subjected to silica gel CC eluted with Hex, EtOAc and $\mathrm{MeOH}$, pure or in mixtures of increasing polarity, providing 117 fractions of $3 \mathrm{~mL}$ each. After solvent evaporation from fractions 33 to 47 (eluted with Hex/EtOAc 2:8), a white solid in the form of flakes was obtained $(14.0 \mathrm{mg}), 0.7 \%$ yield and $\mathrm{mp} 154.2-158.8{ }^{\circ} \mathrm{C}$. This solid was identified as $11 \alpha$-hydroxylup-20(29)-en-3-one (1).

Fractions $66-85$ produced an orange solid $(314.0 \mathrm{mg}), 15.7 \%$ yield, mp 145.0-147.9 ${ }^{\circ} \mathrm{C}$, which was identified as tingenone (5).

Fractions 94-102 produced an amorphous brown solid (300.9 $\mathrm{mg}$ ) which was subjected to silica gel CC eluted with Hex, EtOAc and $\mathrm{MeOH}$, pure or in mixtures of increasing polarity, providing 294 fractions of $3 \mathrm{~mL}$ each. Solvent evaporation from fractions 121 to 133 (eluted with EtOAc) produced a light yellow solid (7.9 mg), 0.4\% yield, mp 218.7-221.4 ${ }^{\circ} \mathrm{C}$ which was identified as 6-oxo-tingenol (6).

The extracts EAE, EAS and ME have yet to be submitted to phytochemical studies. However phytochemical prospection ${ }^{17}$ allowed the detection of the presence of alkaloids, flavonoids and catechin.

\section{Biological assays}

Antimicrobial activity

To evaluate antibacterial and antifungal activity, the microdilution 
method was used to determine the average minimal inhibitory concentrations inhibiting the growth of $50 \%\left(\mathrm{MIC}_{50}\right)$ and $90 \%\left(\mathrm{MIC}_{90}\right)$ of the microorganisms. ${ }^{18}$ All extracts and the triterpenes $\mathbf{1 , 5}$ and $\mathbf{6}$ were tested against Salmonella typhimurium (ATCC 13311), Escherichia coli (ATCC 25723), Staphylococcus aureus (ATCC 25923), Bacillus cereus (ATCC 11778) and Candida albicans (ATCC 18804). The bacteria and the fungus were maintained in brain heart infusion (BHI) culture medium, at $7^{\circ} \mathrm{C}$. An initial duplicate screening was carried out using disposable microplates with all samples being tested at a concentration of $100.00 \mu \mathrm{g} / \mathrm{mL}$. In this step, all extracts and the triterpenes 1, 5 and $\mathbf{6}$ showed antimicrobial activity. Subsequently, these were tested at concentrations of $250.00,125.00,62.50,31.30$, $15.60,7.81,3.91,1.95,0.98,0.49,0.24$ and $0.12 \mu \mathrm{g} / \mathrm{mL}$ to determine the minimal inhibitory concentration $\left(\mathrm{MIC}_{50}\right.$ and $\left.\mathrm{MIC}_{90}\right)$. All 12 microdilution assays were performed in duplicate. Chloramphenicol $\left(\mathrm{MIC}_{50}=0.24 \mu \mathrm{g} / \mathrm{mL}\right.$ and $\left.\mathrm{MIC}_{90}=15.60 \mu \mathrm{g} / \mathrm{mL}\right)$ was used as a positive control for bacteria and miconazole $\left(\mathrm{MIC}_{50}=3.32 \mu \mathrm{g} / \mathrm{mL}\right.$ and $\mathrm{MIC}_{90}$ $=600.48 \mu \mathrm{g} / \mathrm{mL}$ ) for $C$. albicans. The inocula of bacteria and fungus used in experiments contained $4.16 \times 10^{3}$ cells $/ \mathrm{mL}$. At the end of incubation time $(24 \mathrm{~h})$, the plates were analyzed using a Microplate TP-Reader (Thermoplate, Brazil).

\section{Evaluation of toxic potential through Artemia salina larvicidal activity}

The cysts of Artemia salina for the test were acquired in Belo Horizonte City, MG, Brazil. The A. salina cysts $(10 \mathrm{mg})$ were added to $100 \mathrm{~mL}$ of synthetic marine salt solution $(38.0 \mathrm{~g} / \mathrm{L})$ previously prepared using deionized water, and maintained under artificial light at $28{ }^{\circ} \mathrm{C}$. Larvae hatching occurred after $24 \mathrm{~h}$ of incubation time. Lapachol, a compound with proven anti-A. salina effect, was used as the control. The extracts and terpenes $\mathbf{1 , 3}, \mathbf{4}, \mathbf{5}$ and $\mathbf{6}$ isolated from M. imbricata were submitted to larvicidal assays, at concentrations ranging from 1000.00 to $0.06 \mu \mathrm{g} / \mathrm{mL}$, to determine their toxic potential. The concentration range was chosen based on the highest concentration that showed $100 \%$ mortality and at the concentration which induced no death of $A$. salina. The samples were dissolved in DMSO and their concentration ranges were HES and HEE (15.62$0.48 \mu \mathrm{g} / \mathrm{mL})$, EAS, EAE and ME $(1,000.00-62.50 \mu \mathrm{g} / \mathrm{mL})$, terpene $1(31.25-1.95 \mu \mathrm{g} / \mathrm{mL}), 3$ and $4(125.00-7.81 \mu \mathrm{g} / \mathrm{mL}), \mathbf{5}(0.97-0.06$ $\mu \mathrm{g} / \mathrm{mL})$ and $\mathbf{6}(500.00-31.25 \mu \mathrm{g} / \mathrm{mL})$. Terpene 2 was not submitted to larvicidal assays against $A$. salina because it was used in another test and an insufficient amount remained for testing.

\section{RESULTS AND DISCUSSION}

\section{Phytochemical study}

Through the phytochemical study of HEE it was possible to isolate the known pentacyclic triterpenes $\mathbf{1 , 2}, \mathbf{3}, \mathbf{4 , 5}$ and $\mathbf{6}$ (Figure 1). The chemical structures of these constituents were identified based on IR, ${ }^{1} \mathrm{H}$ and ${ }^{13} \mathrm{C}$ NMR spectral data, and by comparing with literature data.

Compound 1 was previously isolated through phytochemical study of the aerial part of M. imbricata ${ }^{19}$ In this paper, the isolation of terpenes $\mathbf{2 , 3}, \mathbf{4}, \mathbf{5}$ and $\mathbf{6}$ from $M$. imbricata is reported for the first time.

The profile of IR spectra of compounds $\mathbf{1}$ to $\mathbf{5}$ were in accordance with the published data for pentacyclic triterpenes. ${ }^{20-23}$

The ${ }^{1} \mathrm{H}$ NMR spectrum of 1 disclosed signals of 7 methyl groups [ $\delta 1.69(3 \mathrm{H}), \delta 1.09(3 \mathrm{H}), \delta 1.07(6 \mathrm{H}), \delta 1.06(3 \mathrm{H}), \delta 0.98(3 \mathrm{H})$ and $\delta$ $0.80(3 \mathrm{H})$ ], of methine [triple doublet at $\delta 3.91\left(\mathrm{H} 11_{\text {ax-ax }}, J=10.8 \mathrm{~Hz}\right.$; and $\left.\left.\mathrm{H} 11_{\text {ax-eq, }}, J=4.8 \mathrm{~Hz}\right)\right]$ and of olefin hydrogens $(\delta 4.72$ and $\delta 4.60)$. These data, together with the signals at $\delta 109.95$ (C29) and $\delta 150.22$ (C20) observed in the ${ }^{13} \mathrm{C}$ NMR spectrum, suggested that $\mathbf{1}$ was a
PCTT of lupane series, ${ }^{21}$ which was then compared with the literature. ${ }^{22}$

Seven methyl signals $[\delta 1.69(3 \mathrm{H}), \delta 1.26(3 \mathrm{H}), \delta 1.04(9 \mathrm{H}), \delta 0.96$ $(3 \mathrm{H})$ and $\delta 0.79(3 \mathrm{H})]$, together with the signals of methine hydrogen $\left[\delta 3.93\left(\mathrm{H} 11_{\text {ax-ax }}, J=10.8 \mathrm{~Hz}\right.\right.$ and $\left.\mathrm{H} 11_{\text {ax-eq }}, J=4.8 \mathrm{~Hz}\right)$ and of methine hydrogen $\mathrm{H} 3(\delta 3.21)$, were observed in the ${ }^{1} \mathrm{H}$ NMR spectrum of $2 .{ }^{21}$ Two singlet signals ( $\delta 4.72$ and $\delta 4.59$ ) were attributed to $\mathrm{H} 29$ of terminal double bond. The signals of carbons $[\delta 109.95$ (C29) and $\delta 150.25$ (C20)] confirmed the double bond and suggested 2 as member of the PCTT lupane series. ${ }^{21}$ The NMR spectral data of $\mathbf{2}$ were in accordance with literature data. ${ }^{21}$

The signals in the ${ }^{1} \mathrm{H}$ NMR spectrum of 3 at $\delta 0.77 ; \delta 0.88 ; \delta$ $0.91 ; \delta 0.96 ; \delta 1.00 ; \delta 1.07$ and $\delta 1.18$ were attributed to seven methyl groups, and a doublet at $\delta 0.88$ was associated to another methyl group (C23). These signals are commonly related to PCTT of the friedelane series. ${ }^{21}$ The ${ }^{13} \mathrm{C}$ NMR spectrum of $\mathbf{3}$ revealed signals at $\delta 211.12$ and at $\delta 210.62$ corresponding to ketone carbonyls. The chemical shift values found in the ${ }^{13} \mathrm{C}$ NMR spectrum of terpene 3 were compared with literature data. ${ }^{21}$

The signals at $\delta 0.73 ; \delta 0.87 ; \delta 1.03 ; \delta 1.04 ; \delta 1.05$ and $\delta 1.22$ observed in the ${ }^{1} \mathrm{H}$ NMR spectrum of 4 were associated to 6 methyl groups, and a doublet signal at $\delta 0.88$ to another methyl group (C23), while a doublet at $\delta 3.27$ was attributed to hydrogen linked to hydroxylated carbon. The ${ }^{13} \mathrm{C}$ NMR spectrum disclosed signals at $\delta 6.83$ assigned to methyl carbon (C23) of PCTT friedelane, ${ }^{21}$ at $\delta 213.18$ attributed to carbonyl (C3) and at $\delta 74.78$ assigned to hydroxylated carbon (C29). The NMR data of terpene 4 were in accordance with published data. $^{21}$

The profile of the IR spectrum, especially in the region between $1500-1708 \mathrm{~cm}^{-1}$, characteristic of $\mathrm{C}=\mathrm{O}$ and $\mathrm{C}=\mathrm{C}$ bonds, suggested compound $\mathbf{5}$ as a quinone methide PCTT. ${ }^{20}$ The signals observed in the ${ }^{1} \mathrm{H}$ NMR spectrum of 5 at $\delta 0.98 ; \delta 1.01 ; \delta 1.35 ; \delta 1.51$ and at $\delta 2.23$ corresponded to 5 methyl groups, a doublet signal at $\delta 1.00$ was attributed to another methyl group (C30); and a doublet at $\delta 2.92$ (H22) and a multiplet at $\delta 2.51$ were associated to hydrogen linked to C20. These spectral data, together with the doublet signal at $\delta 7.03$ and at $\delta 6.38$; and a singlet at $\delta 6.55$, confirmed 5 as being a quinone methide triterpene. ${ }^{21}$ The carbon signals at $\delta 178.43$ (C2) and at $\delta$ 213.58 (C21) were attributed to carbonyl carbons. The chemical shift values found in the ${ }^{13} \mathrm{C}$ NMR spectrum of terpene 5 were consistent with the literature data. ${ }^{23}$

The IR spectrum of 6 revealed bands at 1592 and $1458 \mathrm{~cm}^{-1}$ that were associated to the $\mathrm{C}=\mathrm{C}$ bond of aromatic compound. ${ }^{20}$ Six methyl signals [singlets at $\delta 2.63 ; \delta 1.58 ; \delta 1.38 ; \delta 1.00$ and $\delta 0.99$, as well as a doublet at $\delta 0.99(\mathrm{C} 30)]$, were identified in the ${ }^{1} \mathrm{H}$ NMR spectrum of 6. Two singlets, at $\delta 6.86(\mathrm{H} 1)$ and at $\delta 6.25(\mathrm{H} 7)$, confirmed the aromatic and olefin hydrogens, respectively. The carbon signals at $\delta 187.94$ (C6) and at $\delta 214.69$ (C21) were associated to carbonyls. The chemical shift values found in the ${ }^{13} \mathrm{C}$ NMR spectrum of terpene 6 were consistent with the literature data. ${ }^{24}$

\section{Antimicrobial activity}

The level of resistance or sensitivity of the bacteria and fungus to the samples was determined by the presence or absence of growth. The results of $\mathrm{MIC}_{50}$ of the extracts and triterpenes from $M$. imbricata subjected to antimicrobial assays are shown in Table 1.

In accordance with the results, it was found that all samples showed $\mathrm{MIC}_{50}$ within the concentration range used in the experiments. The solid HES, extract HEE, and terpene $\mathbf{5}$ showed better inhibition of $S$. aureus growth. Azithromycin is a macrolide antibiotic that suppresses the biosynthesis of protein, retards bacterial growth, or causes death of microorganisms, when tested against $S$. aureus presented a $\mathrm{MIC}_{50}$ of $4.0 \mu \mathrm{g} / \mathrm{mL}{ }^{25}$ This represents a lower activity 
Table 1. Minimal inhibitory concentrations that inhibit 50\% of the microorganism growth $\left(\mathrm{MIC}_{50}\right)$ determined for the extracts and compounds isolated from $M$. imbricata against pathogenic microorganisms

\begin{tabular}{|c|c|c|c|c|c|}
\hline \multirow{2}{*}{ Extracts and compounds } & \multicolumn{5}{|c|}{ Minimal Inhibitory Concentration $\left(\mathrm{MIC}_{50}\right)(\mu \mathrm{g} / \mathrm{mL})$} \\
\hline & S. typhimurium & E. coli & S. aureus & B. cereus & C. albicans \\
\hline HES & 125.00 & 125.00 & 0.12 & 125.00 & 0.49 \\
\hline HEE & 125.00 & 125.00 & 0.12 & 250.00 & 0.12 \\
\hline EAS & 125.00 & 125.00 & 31.30 & 125.00 & 62.50 \\
\hline EAE & 250.00 & 250.00 & 31.30 & 125.00 & 31.30 \\
\hline ME & 125.00 & 250.00 & 31.30 & 125.00 & 15.60 \\
\hline 1 & 250.00 & 250.00 & 62.50 & 250.00 & 125.00 \\
\hline 5 & 62.50 & 125.00 & 0.12 & 125.00 & 0.12 \\
\hline 6 & 31.30 & 125.00 & 62.50 & 250.00 & 62.50 \\
\hline chloranfenicol & 0.24 & 0.24 & 0.24 & 0.24 & - \\
\hline miconazole & - & - & - & - & 3.32 \\
\hline
\end{tabular}

than that found for HES, HEE, and for terpene 5, which showed a lower value for $\mathrm{MIC}_{50}$. All extracts and terpenes $\mathbf{5}$ and $\mathbf{6}$ induced a high rate of growth inhibition of $C$. albicans (Table 1). Fluconazole is an antifungal used to treat infectious diseases caused by fungus. In assays with $C$. albicans, fluconazole showed a $\mathrm{MIC}_{50}$ of $1.1 \mu \mathrm{g} / \mathrm{mL} .^{26}$ The $\mathrm{MIC}_{50}$ value found using HES, HEE and terpene 5, indicated its higher activity against $C$. albicans, evidencing their potential as antifungal agents.

The extract from leaves of Maytenus ilicifolia showed no activity against Salmonella sp. ${ }^{27}$ However, in this work, it was verified that all extracts as well as the compounds $\mathbf{1 , 5}$ and $\mathbf{6}$, obtained from roots of M. imbricata were active against Salmonella typhimurium.

As shown in Table 2, higher antimicrobial activity was found for the extract $\mathrm{HEE}$ against $S$. aureus $\left(\mathrm{MIC}_{90}=0.12 \mu \mathrm{g} / \mathrm{mL}\right)$ and for $\mathrm{ME}$ against $C$. albicans $\left(\mathrm{MIC}_{90}=31.30 \mu \mathrm{g} / \mathrm{mL}\right)$.

Vancomycin, an antibiotic highly effective against Gram-positive bacteria, has being adopted as a first choice for the treatments of infectious diseases caused by $S$. aureus. This is the main pathogen associated to hospital-acquired infections. In assays in vitro against $S$. aureus, vancomycin presented a value higher $\left(\mathrm{MIC}_{100}=1.5 \mu \mathrm{g} / \mathrm{mL}\right)^{28}$ value than that found for $\mathrm{HEE}\left(\mathrm{MIC}_{90}=0.12 \mu \mathrm{g} / \mathrm{mL}\right)$.

Neomycin is an antibiotic used to prevent or treat skin infections caused by bacteria, including $S$. aureus. Jain et al. ${ }^{29}$ tested neomycin against $S$. aureus, and found $\mathrm{MIC}_{100}=190.0 \mu \mathrm{g} / \mathrm{mL}$, a value higher than the $\mathrm{MIC}_{90}$ of HES, HEE and compound 5. These authors also tested the ethanol extract from roots of Maytenus senegalensis against $S$. aureus and found $\mathrm{MIC}_{100}=1250.0 \mu \mathrm{g} / \mathrm{mL}$. This value is higher than the $\mathrm{MIC}_{90}$ found for the extracts HES, HEE, EAS and for terpenes $\mathbf{1 , 5}$ and $\mathbf{6}$ (Table 2).

The methanol extract (ME) was active against $B$. cereus. This bacterium showed high sensitivity when treated with ME extract. In addition, this extract also presented activity against $E$. coli and C. albicans.

Considering the results of the in vitro assays with bacteria and Candida albicans, a high antibacterial and antifungal activity was attributed to the extracts and terpenes isolated from roots of $M$. imbricata.

\section{Evaluation of cytotoxic potential}

The toxicity assays using Artemia salina, a marine microcrustacean, were carried out according to the methodology described by Pimenta et al. ${ }^{30}$ The experiments were performed in triplicate and the lethal concentration of sample necessary to induce $50 \%$ death $\left(\mathrm{LC}_{50}\right)$ of brine shrimps, was established using the Probit Method, a parametric statistical procedure with a $95 \%$ confidence interval.

Table 2. Minimal inhibitory concentrations that inhibit $90 \%$ of the microorganism growth $\left(\mathrm{MIC}_{90}\right)$ determined for the extracts and compounds isolated from $M$. imbricata against pathogenic microorganisms

\begin{tabular}{|c|c|c|c|c|c|}
\hline \multirow{2}{*}{ Extracts and compounds } & \multicolumn{5}{|c|}{ Minimal Inhibitory Concentration $\left(\mathrm{MIC}_{90}\right)(\mu \mathrm{g} / \mathrm{mL})$} \\
\hline & S. typhimurium & E. coli & S. aureus & B. cereus & C. albicans \\
\hline HES & ND & ND & 125.00 & ND & ND \\
\hline HEE & 250.00 & ND & 0.12 & ND & 62.50 \\
\hline EAS & ND & ND & 250.00 & ND & 125.00 \\
\hline EAE & ND & ND & ND & ND & 250.00 \\
\hline ME & ND & 250.00 & ND & 250.00 & 31.30 \\
\hline 1 & ND & ND & 250.00 & ND & 250.00 \\
\hline 5 & 125.00 & 125.00 & 125.00 & ND & 125.00 \\
\hline 6 & ND & ND & 250.00 & ND & ND \\
\hline chloranfenicol & 15.6 & 15.6 & 15.6 & 15.6 & - \\
\hline miconazole & - & - & - & - & 600.48 \\
\hline
\end{tabular}

ND $=$ Not Detected 
Extracts of plants or compounds submitted to assays with $A$ salina are considered active when the $\mathrm{LC}_{50}$ is less than $1000.0 \mu \mathrm{g} / \mathrm{mL} .{ }^{31}$ The evaluation of toxicity using A. salina was performed with the extracts HES, HEE, EAS, EAE and ME, and compounds 1, 3, 4, 5 and $\mathbf{6}$, followed by the respective determination of $\mathrm{LC}_{50}$ (Table 3 ).

Table 3. Average lethal dose $\left(\mathrm{LC}_{50}\right)$ of extracts and terpenes isolated from roots of Maytenus imbricata against A. salina

\begin{tabular}{ccc}
\hline \multirow{2}{*}{$\begin{array}{c}\text { Extracts and } \\
\text { compounds }\end{array}$} & \multicolumn{2}{c}{ Toxicity against A. salina } \\
\cline { 2 - 3 } & $\mathrm{LC}_{50}(\mu \mathrm{g} / \mathrm{mL})$ & Confidence limit $(95 \%)$ \\
\hline $\mathrm{HES}$ & 2.10 & $1.66<\mathrm{LC}_{50}<2.65$ \\
$\mathrm{HEE}$ & 2.53 & $0.97<\mathrm{LC}_{50}<3.09$ \\
EAS & 236.16 & $197.92<\mathrm{LC}_{50}<281.79$ \\
EAE & 295.87 & $244.36<\mathrm{LC}_{50}<358.24$ \\
$\mathrm{ME}$ & 384.93 & $308.47<\mathrm{LC}_{50}<480.34$ \\
1 & 9.28 & $7.69<\mathrm{LC}_{50}<11.20$ \\
3 & 26.05 & $19.60<\mathrm{LC}_{50}<34.62$ \\
4 & 47.43 & $39.83<\mathrm{LC}_{50}<56.48$ \\
5 & 0.15 & $0.11<\mathrm{LC}_{50}<0.19$ \\
6 & 33.74 & $26.13<\mathrm{LC}_{50}<43.58$ \\
lapachol & 70.00 & $61.00<\mathrm{LC}_{50}<81.00$ \\
\hline
\end{tabular}

$\mathrm{LC}_{50}=$ concentration that causes $50 \%$ death.

The extracts HES and HEE and all terpenes showed high toxicity, evidenced by their low $\mathrm{LC}_{50}$ values (Table 3 ). Tingenone (5) is a pentacyclic triterpene with known cytotoxic properties. ${ }^{32}$ In the present work, this terpene showed higher toxicity when compared to the other samples of $M$. imbricata tested. This terpene is the main constituent found in the extracts HES (40\%) and HEE (9.4\%). Thus, it is possible to assign the high cytotoxicity observed for these two extracts to compound 5. Using Artemia franciscana, Macari et al. ${ }^{33}$ studying Maytenus guyanensis found $\mathrm{LC}_{50}=363 \mu \mathrm{g} / \mathrm{mL}$ for the hexane extract of barks. Based on this $\mathrm{LC}_{50}$, these authors considered this extract as being a potential larvicide product. Through the assay with A. salina, it was found that, except for the extract ME, all other samples presented values of $\mathrm{LC}_{50}$ lower than $363 \mu \mathrm{g} / \mathrm{mL}$. Based on these results can be established that substances from $M$. imbricata also represent potential larvicide agents. Bouzada et al., ${ }^{34}$ using a similar methodology with $A$. salina, found $\mathrm{LC}_{50}>250 \mu \mathrm{g} / \mathrm{mL}$ for the methanol extract from leaves of Maytenus ilicifolia. On the other hand, ethanol extract of Maytenus obtusifolia was considered of low toxicity to the larvae of $A$. salina, with $\mathrm{LC}_{50}$ greater than $1000 \mathrm{mg} / \mathrm{mL} .{ }^{35}$ The values of this average lethal dose $\left(\mathrm{LC}_{50}\right)$ are high when compared with those found for HES and HEE in the present work (Table 3). Since the extracts and terpenes showed good activity against $A$. salina it is possible to conclude that they also have potential antitumor, pesticide, trypanosomicide and/or molluscicide activities. ${ }^{15}$

\section{CONCLUSION}

The triterpenes $11 \alpha$-hydroxylup-20(29)-en-3-one, 3 $\beta, 11 \alpha$-dihydroxylup-20(29)-ene, 3,7-dioxofriedelane, 3-oxo-29-hydroxyfriedelane, tingenone and 6-oxo-tingenol were isolated from roots of Maytenus imbricata. All extracts, and the terpenes $11 \alpha$-hydroxylup20(29)-en-3-one, tingenone and 6-oxo-tingenol, were active against $S$. typhimurium, E. coli, S. aureus, B. cereus and C. albicans. The extracts HES and HEE and the terpenes 1, 3, 4, 5 and $\mathbf{6}$ showed representative larvicidal effects against Artemia salina. The results of this work indicate the promising potential of this plant as a larvicide, or as a source of drugs with antimicrobial or antitumor properties.

\section{SUPPLEMENTARY MATERIAL}

The Figures 1S-21S present spectra of IR, ${ }^{1} \mathrm{H}$ and ${ }^{13} \mathrm{C}$ NMR of compounds isolated of hexane/ethyl ether (1:1) extract of the roots of $M$. imbricata. The Tables $1 \mathrm{~S}-6 \mathrm{~S}$ present comparison of ${ }^{13} \mathrm{C} \mathrm{NMR}$ data of compounds and of literature. This supplementary material is available free of charge at http://quimicanova.sbq.org.br, as PDF file.

\section{ACKNOWLEDGMENTS}

The authors are grateful to Conselho Nacional de Desenvolvimento Científico e Tecnológico $(\mathrm{CNPq})$ and Fundação de Amparo à Pesquisa do Estado de Minas Gerais (FAPEMIG) by financial support.

\section{REFERENCES}

1. Shirota, O.; Tamemura, T.; Morita, H.; Takeya, K.; Itokawa, H.; J. Nat. Prod. 1996, 59, 1072; Orabi, K. Y.; Al-Qasoumi, S. I.; El-Olemy, M. M.; Mossa, J. S.; Muhammad, I.; Phytochemistry 2001, 58, 475.

2. Corsino, J.; Furlam, M.; Bolzani, V. da S.; Pereira, A. M. S.; Franca, S. E.; Phytochemistry 1998, 49, 2181; González, A. G.; Tincusi, B. M.; Bazzocchi, I. L.; Tokuda, H.; Nishino, H.; Konoshima, T.; Jiménez, I. A.; Ravelo, A. G.; Bioorg. Med. Chem. 2000, 8, 1773.

3. Sannomiya, M.; Vilegas, W.; Rastrelli, L.; Pizza, C. A.; Phytochemistry 1998, 49, 237

4. Tiberti, L. A.; Yariwake, J. H.; Ndjoko, K.; Hostettmann, K.; J. Chromatogr., B: Anal. Technol. Biomed. Life Sci. 2007, 846, 378; Souza, L. M.; Cipriani, T. R.; Sant'Ana, C. F.; Iacomini, M.; Gorin, P. A. J.; Sassaki, G. L.; J. Chromatogr., A 2009, 1216, 99.

5. De Souza, L. M.; Cipriani, T. R.; Iacomini, M.; J. Pharm. Biomed. Anal. 2008, 47, 59 .

6. Souza, S. A. M.; Cattelan, L. V.; Vargas, D. P. V.; Piana, C. F. B.; Bobrowski, V. L.; Rocha, B. H. G.; Ci. Biol. Saúde 2005, 11, 7; Dias, K. S.; Marques, M. S.; Menezes, I. A. C.; Santos, T. C.; Silva, A. B. L.; Estevam, C. S.; Sant'Ana, A. E. G.; Pizza, C.; Antoniolli, A. R.; Marcal, R. M.; Fitoterapia 2007, 78, 460 .

7. Hussein, G.; Nakamura, N.; Meselhy, M. R.; Hattorim, M.; Phytochemistry 1999, 50, 689 .

8. Jeller, A. H.; Silva, D. H. S.; Lião, L. M.; Bolzani, V. S.; Furlan, M.; Phytochemistry 2004, 6, 1977; Nakagawa, H.; Takaishi, Y.; Fujimoto, Y.; Duque, C.; Garzon, C.; Sato, M.; Okamoto, M.; Oshikawa, T.; Ahmed, S. U.; J. Nat. Prod. 2004, 67, 1919; Perestelo, N. R.; Jiménez, I. A.; Tokuda, H.; Hayashi, H.; Bazzocchi, I. L.; J. Nat. Prod. 2010, 73, 127.

9. Baggio, C. H.; Freitas, C. S.; Otofuji, G. M.; Cipriani, T. R.; Souza, L. M.; Sassaki, G. L.; Iacomini, M.; Rieck, L.; Mesia-Vela, S.; Marques, M. C. A.; J. Ethnopharmacol. 2007, 113, 433; Cipriani, T. R.; Mellinger, C. G.; Souza, L. M.; Baggio, C. H.; Freitas, C. S.; Marques, M. C. A.; Gorin, P. A. J.; Sassaki, G. L.; Iacomini, M.; Carbohydr. Polym. 2009, $5,361$.

10. Sosa, S.; Morelli, C. F.; Tubaro, A.; Cairoli, P.; Speranza, G.; Manitto, P.; Phytomedicine 2007, 14, 109.

11. Niero, R.; Andrade, S. F.; Cechinel Filho, V.; Curr. Pharm. Des. 2011, 17, 1851.

12. Rojas, R.; Bustamante, B.; Bauer, J.; Fernandez, I.; Alban, J.; Lock, O.; J. Ethnopharmacol. 2003, 88, 199.

13. Ferreira, V. F.; Pinto, A. C.; Quim. Nova 2010, 33, 1829.

14. Novais, T. S.; Costa, J. F. O.; David, J. P. L.; David, J. M.; Queiroz, L. P.; França, F.; Giulietti, A. M.; Soares, M. B. P.; Santos, R. R.; Rev. Bras. Farmacogn. 2003, 14, 8; Bolzan, A. A.; Silva, C. M.; Francescato, L. N.; Murari, A. L.; Silva, G. N. S.; Heldwein, C. G.; Heinzmann, B.; Lat. Am. J. Pharm. 2007, 26, 619. 
15. McLaughin, J. L.; Rogers, L. L.; Anderson, J. E.; Drug Information J. 1998, 32, 513.

16. Silva, G. D. F.; Silva, S. R. S.; Barbosa, L. C. A.; Duarte, L. P.; Ribeiro, S. M. R.; Queiroz, J. H.; Vieira Filho, S. A.; Oliveira, M. L. R.; Rev. Bras. Farmacogn. 2009, 19, 530; Silva, S. R. S.; Silva, G. D. F.; Barbosa, L. C. A.; Duarte, L. P.; King-Diaz, B.; Archundia-Camacho, F.; Lotina-Hennsen, B.; Pest. Biochem. Physiol. 2007, 87, 109.

17. Matos, F. J. A.; Introdução à Fitoquímica Experimental, Ed. UFC: Fortaleza, 1980

18. Zacchino, A. S.; Gupta, M. P.; Manual de técnicas in vitro para la detección de compuestos antifúngicos, Corpus Editorial y Distribuidora: Rosario 2007, vol. 85.

19. Silva, S. R. S.; Silva, G. D. F.; Barbosa, L. C. A.; Duarte, L. P.; Vieira Filho, A. S.; Helv. Chim. Acta 2005, 88, 1102.

20. Silverstein, R. M.; Webster, F. X.; Kiemle, D. J.; Identificação Espectrométrica de Compostos Orgânicos, $7^{\mathrm{a}}$ ed., LTC: Rio de Janeiro, 2007.

21. Mahato, S. B.; Kundu, A. P.; Phytochemistry 1994, 37, 1517.

22. Silva, S. R. S.; Tese de Doutorado, Universidade Federal de Minas Gerais, Brasil, 2007.

23. Sotanaphun, U.; Suttisri, R.; Lipipun, V.; Bavovada, R.; Phytochemistry 1998, 49, 1749.

24. Gonzaléz, A. G.; Alvarenga, N. L.; Ravelo, A. G.; Jiménez, I. A.; Bazzochi, I. L.; Canela, N. J.; Moujir, L. M.; Phytochemistry 1996, 43, 129.
25. Pereira, I. A.; Soares, L. C.; Coelho, S. M. O.; Balbino, F. A.; Pribul, B. R.; Souza, M. M. S.; Arq. Brasil. de Med. Veterinária Zoot. 2009, 61, 577.

26. Bedout, C.; Ayabaca, J.; Veja, R.; Méndez, M.; Santiago, A. R.; Pabón, M. L.; Tabares, A.; Arango, M.; Restrepo, A.; Newell, V.; Biomédica 2003, 23, 31 .

27. Voss-Rech, D.; Klein, C. S.; Techio, V. H.; Scheuermann, G. N.; Rech, G.; Fiorentin, L.; Ciência Rural 2011, 41, 314.

28. França, H. S.; Kuster, R. M.; Rito, P. N.; Oliveira, A. P.; Teixeira, L. A.; Rocha, L.; Quim. Nova 2009, 32, 1103.

29. Jain, N.; Light, M. E.; van Staden, J.; S. Afr. J. Bot. 2008, 74, 163.

30. Pimenta, L. P. S.; Pinto, G. B.; Takahashi, J. A.; Silva, L. G. F.; Boaventura, M. A. D.; Phytomedicine 2003, 10, 209.

31. Meyer, B. N.; Ferrigni, N. R.; Putnan, J. E.; Jacobsen, L. B.; Nicholas, D. E.; McLaughlin, J. L.; Planta Med. 1982, 45, 31.

32. Ravelo, A. G.; Braun, A. E.; Orellana, H. C.; Sarau, E. P.; Siverio, D. M.; Curr. Top. Med. Chem. 2004, 4, 241.

33. Macari, P. A. T.; Portela, C. N.; Pohlit, A. M.; Acta Amaz. 2006, 36, 513.

34. Bouzada, M. L. M.; Fabri, R. L.; Nogueiro, M.; Konno, T. U. P.; Duarte, G. G.; Scio, E.; Pharm. Biol. 2009, 47, 44.

35. Mota, K. S. L.; Pita, J. C. L. R.; Estevam, E. C.; Medeiros, V. M.; Tavares, J. F.; Agra, M. F.; Diniz, M. F. F. M.; Silva, M. S.; Batista, L. M.; Rev. Bras. Farmacogn. 2008, 18, 441. 
EVALUATION OF ANTIMICROBIAL ACTIVITY AND TOXIC POTENTIAL OF EXTRACTS AND TRITERPENES ISOLATED FROM Maytenus imbricata

Vanessa G. Rodrigues*, Lucienir P. Duarte, Grácia D. F. Silva, Fernando C. Silva, Jefferson V. Góes, Jacqueline A. Takahashi e Lúcia P. S. Pimenta

Departamento de Química, Instituto de Ciências Exatas, Universidade Federal de Minas Gerais, Av. Antônio Carlos, 6627, 31270 901 Belo Horizonte - MG, Brasil

Sidney A. Vieira Filho

Departamento de Farmácia, Escola de Farmácia, Universidade Federal de Ouro Preto, Rua Costa Sena, 171, 35400-000 Ouro Preto - MG, Brasil

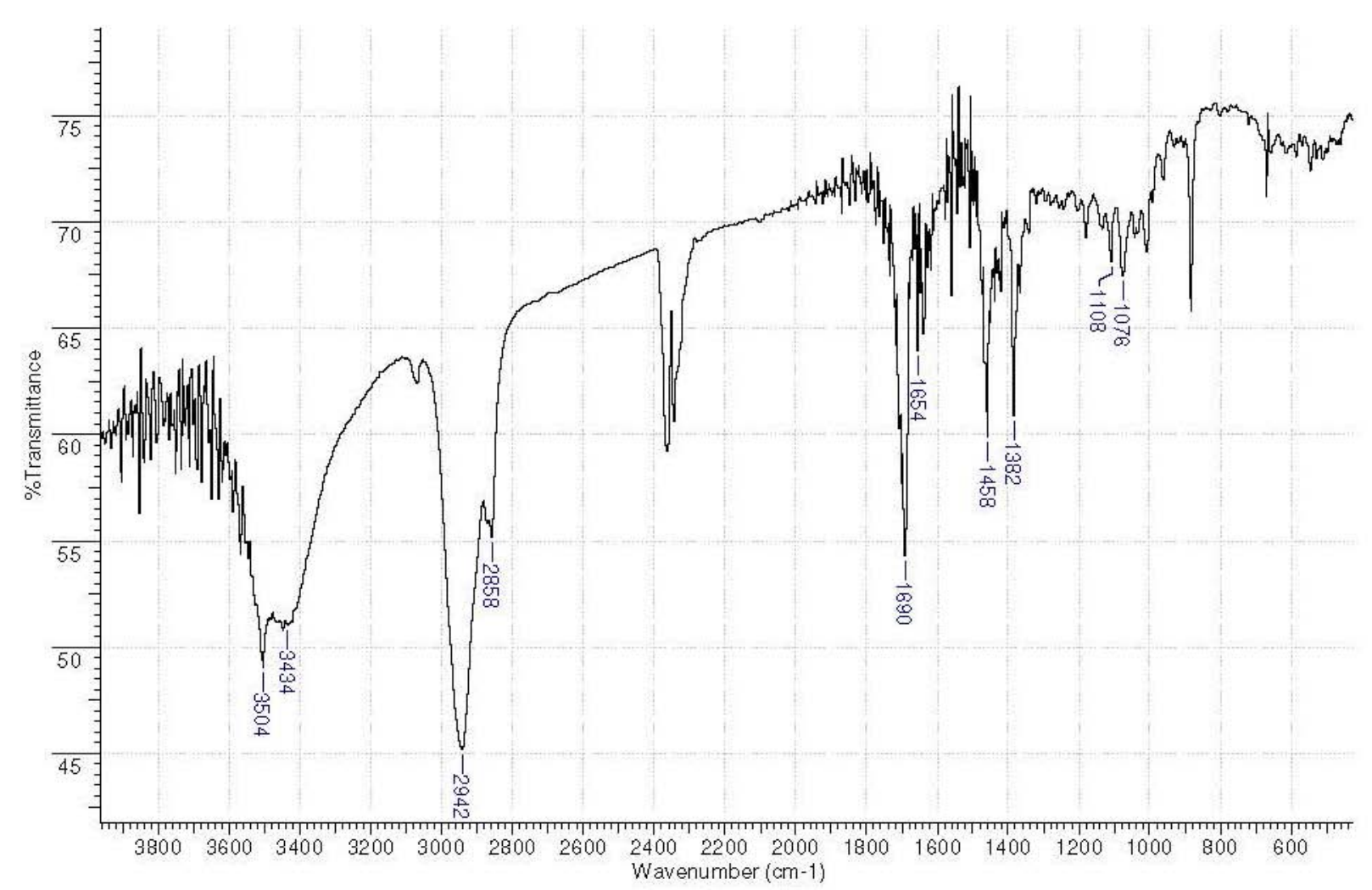

Figure 1S. IR spectrum of compound $1\left(\mathrm{KBr}, \mathrm{cm}^{-1}\right)$ 


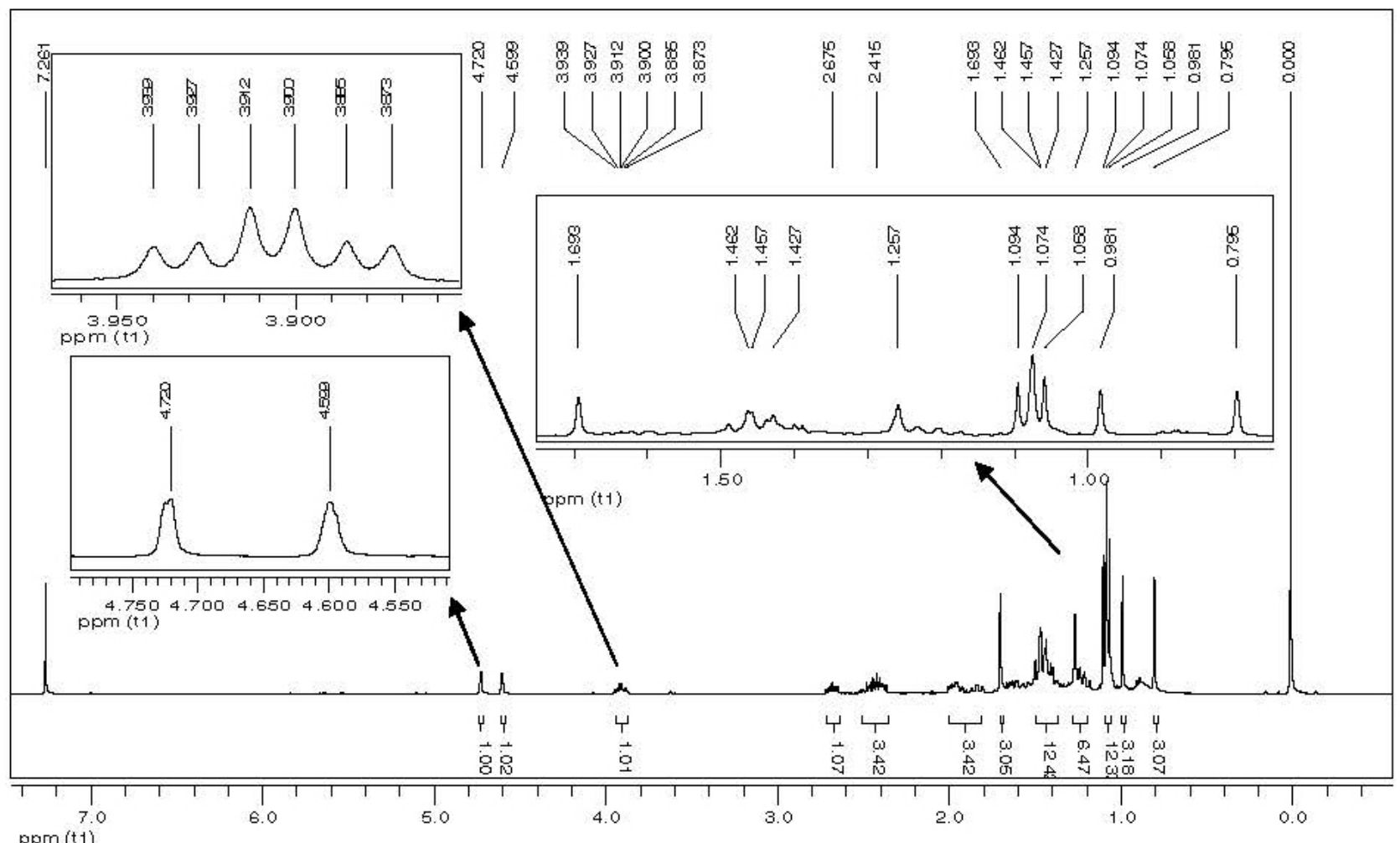

Figure 2S. ${ }^{1} \mathrm{H}$ NMR spectrum of compound $1\left(400 \mathrm{MHz}, \mathrm{CDCl}_{3}\right)$

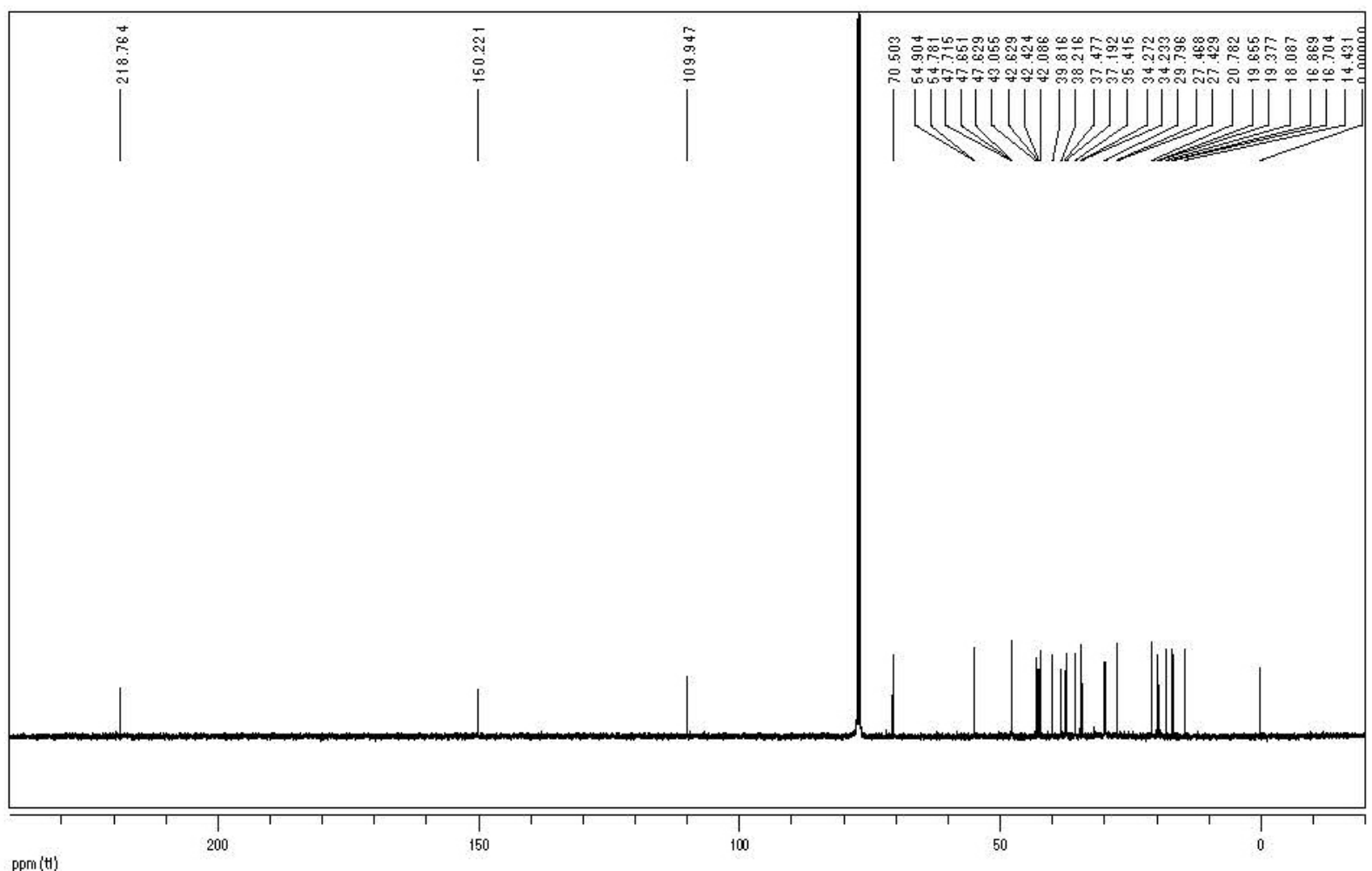

Figure 3S. ${ }^{13} \mathrm{C} \mathrm{NMR}$ spectrum of compound $1\left(100 \mathrm{MHz}, \mathrm{CDCl}_{3}\right)$ 


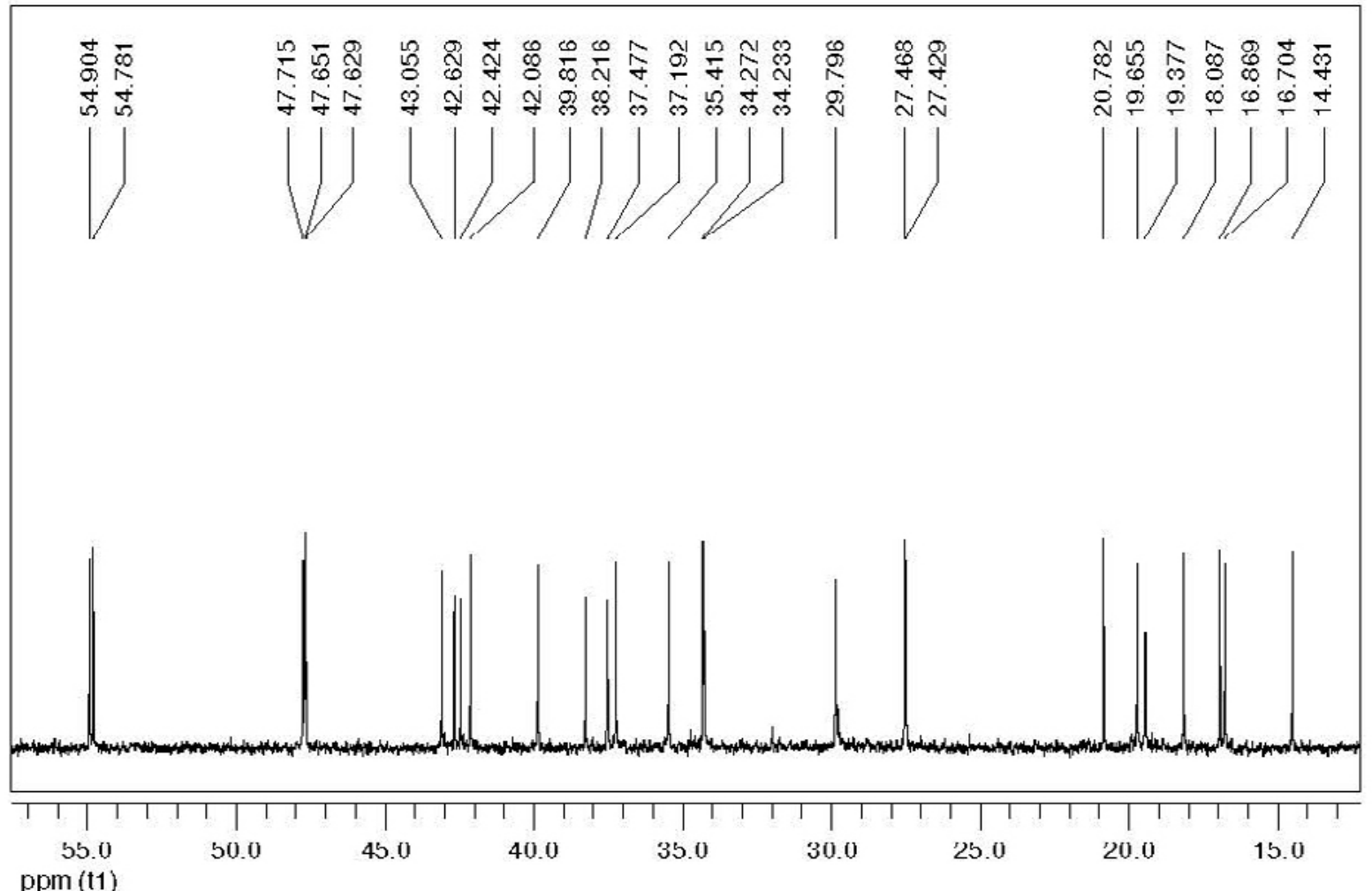

Figure $4 \mathrm{~S} .{ }^{13} \mathrm{C}$ NMR spectrum of compound $1\left(100 \mathrm{MHz}, \mathrm{CDCl}_{3}\right)$

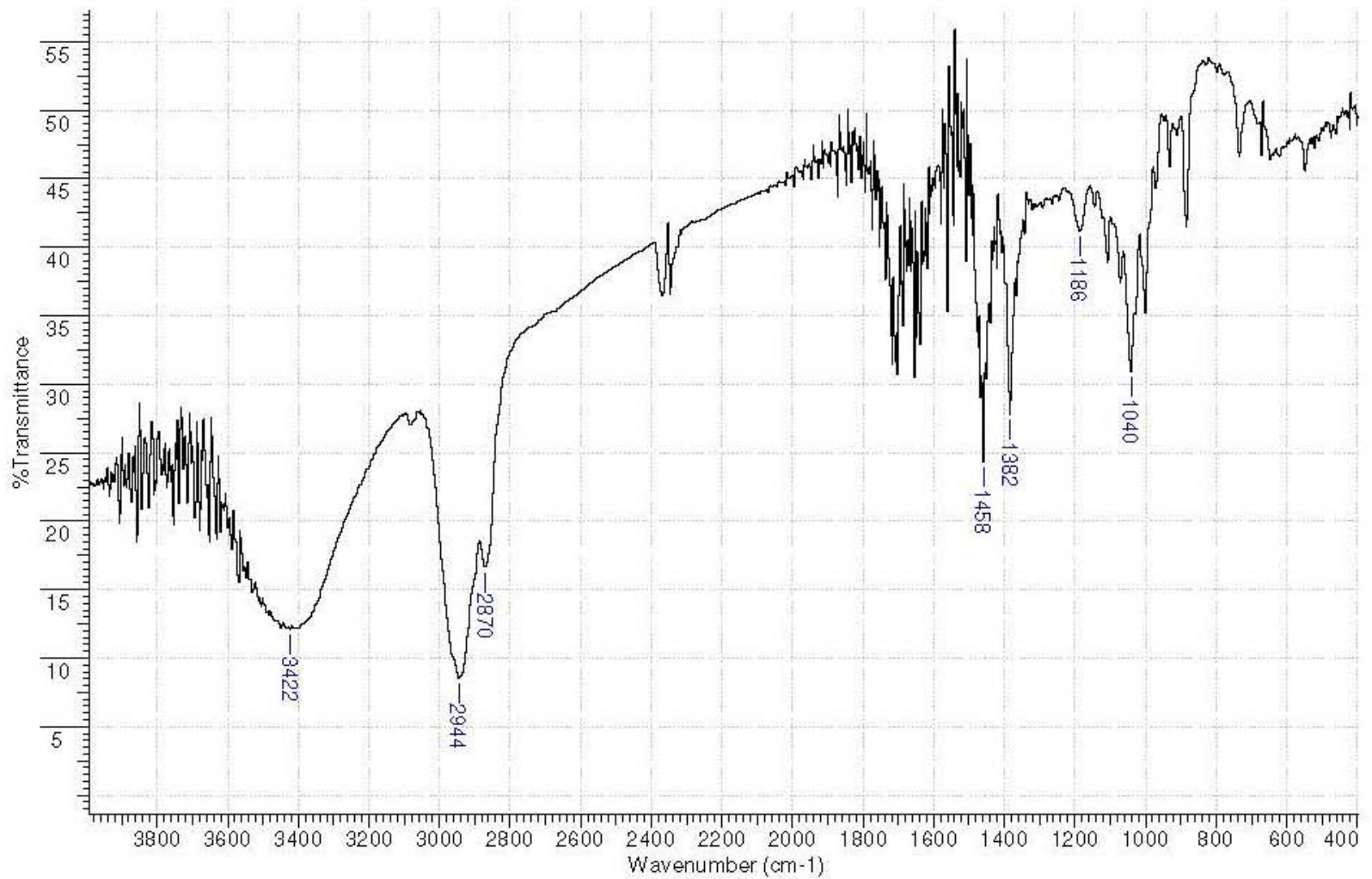

Figure 5S. IR spectrum of compound $2\left(\mathrm{KBr}, \mathrm{cm}^{-1}\right)$ 


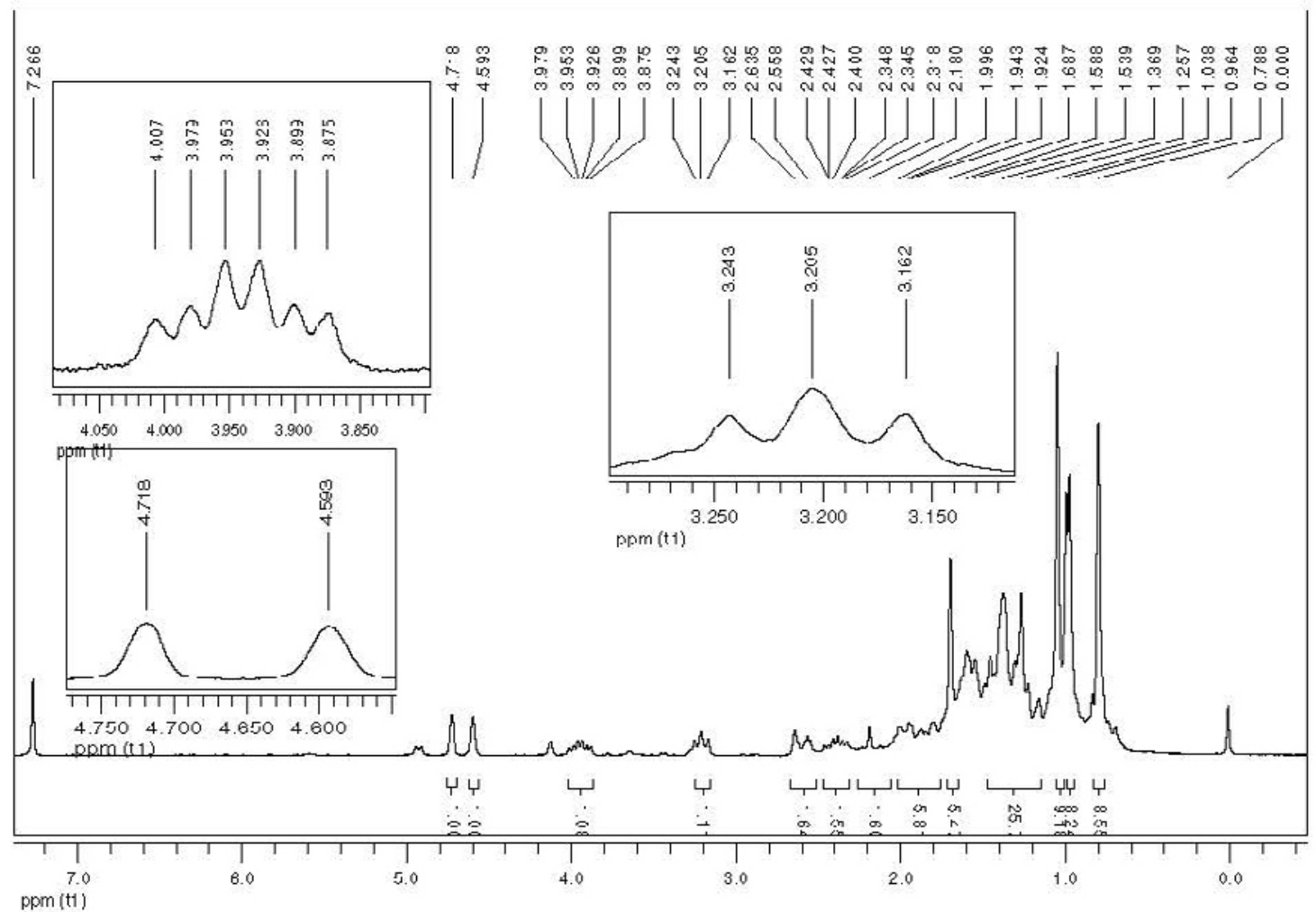

Figure 6S. ${ }^{l} \mathrm{H}$ NMR spectrum of compound $2\left(200 \mathrm{MHz}, \mathrm{CDCl}_{3}\right)$

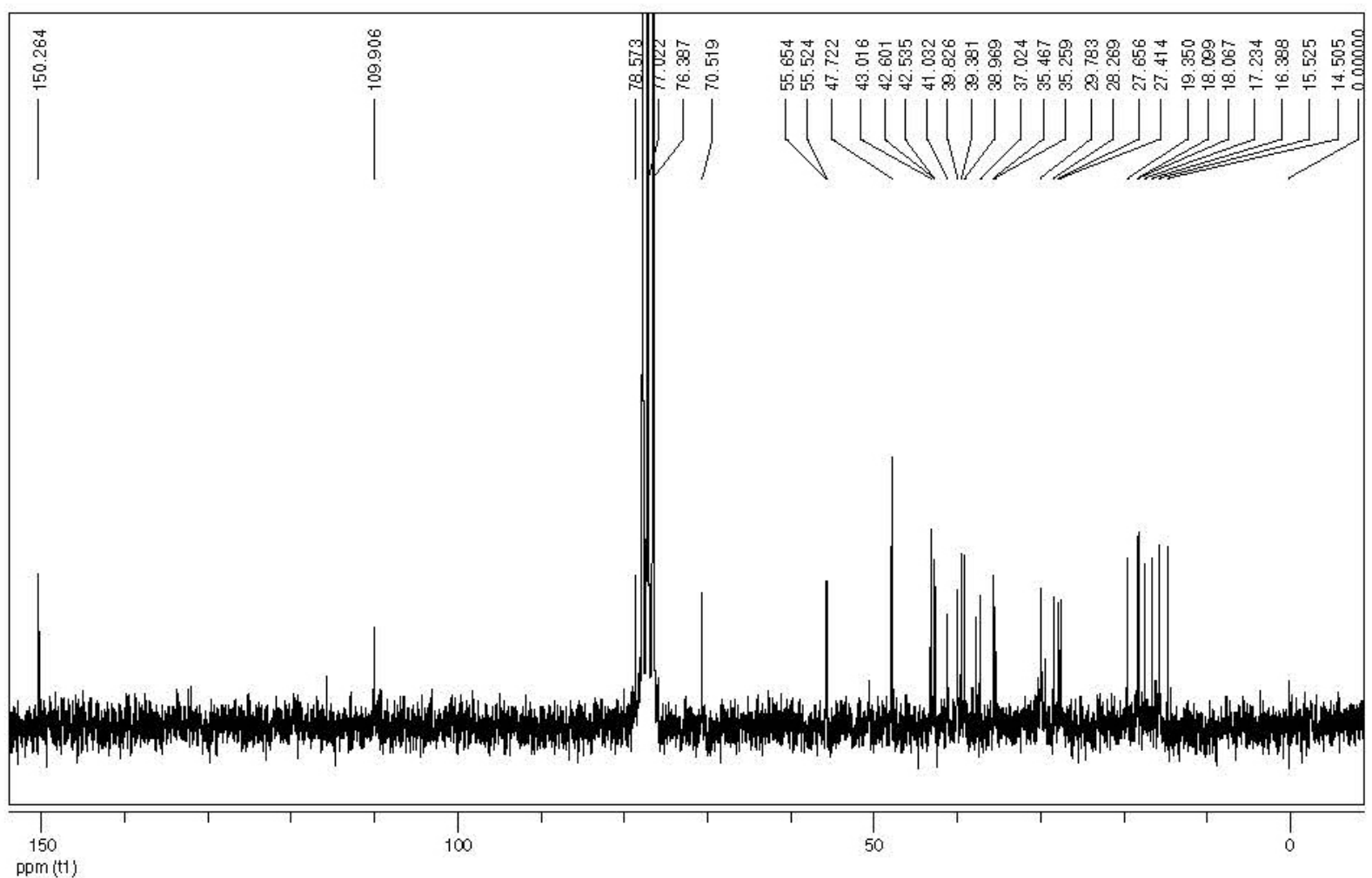

Figure 7S. ${ }^{13} \mathrm{C} \mathrm{NMR} \mathrm{spectrum} \mathrm{of} \mathrm{compound} 2\left(50 \mathrm{MHz}, \mathrm{CDCl}_{3}\right)$ 


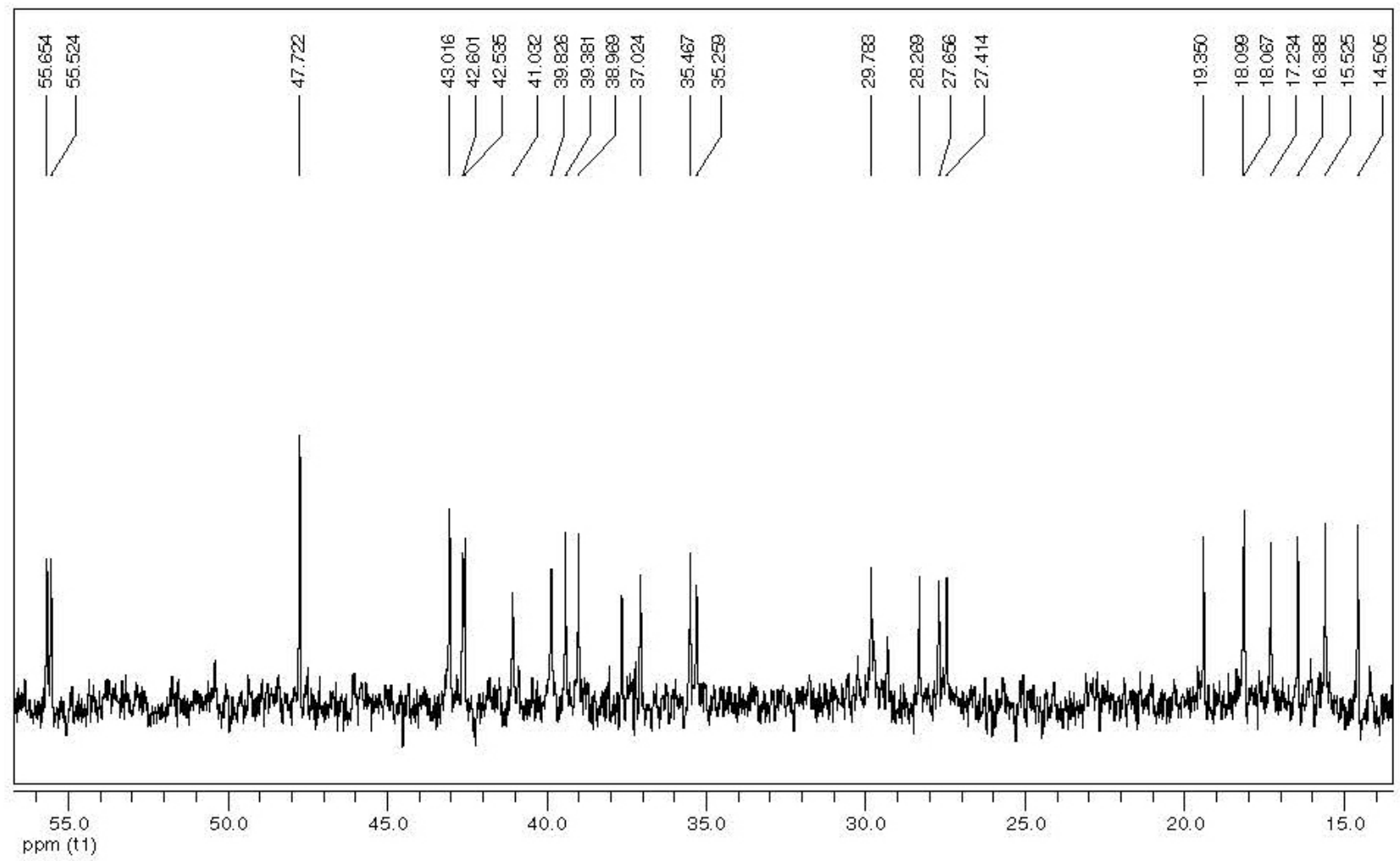

Figure 8S. ${ }^{13} \mathrm{C}$ NMR spectrum of compound $2\left(50 \mathrm{MHz}, \mathrm{CDCl}_{3}\right)$

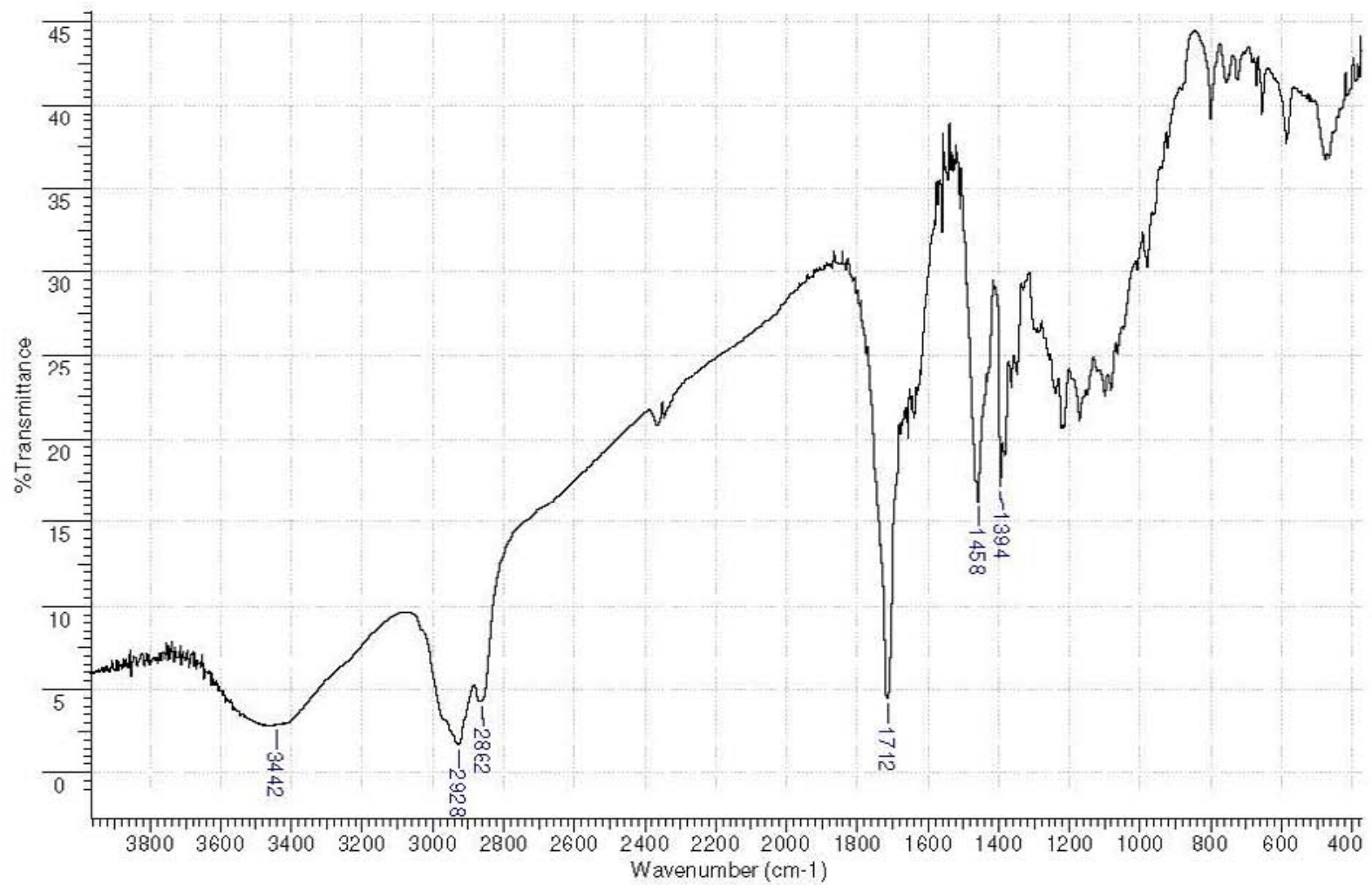

Figure 9S. IR spectrum of compound $3\left(\mathrm{KBr}, \mathrm{cm}^{-1}\right)$. The absorption band at $3442 \mathrm{~cm}^{-1}$ was attributed to moisture in the $\mathrm{KBr}$ 


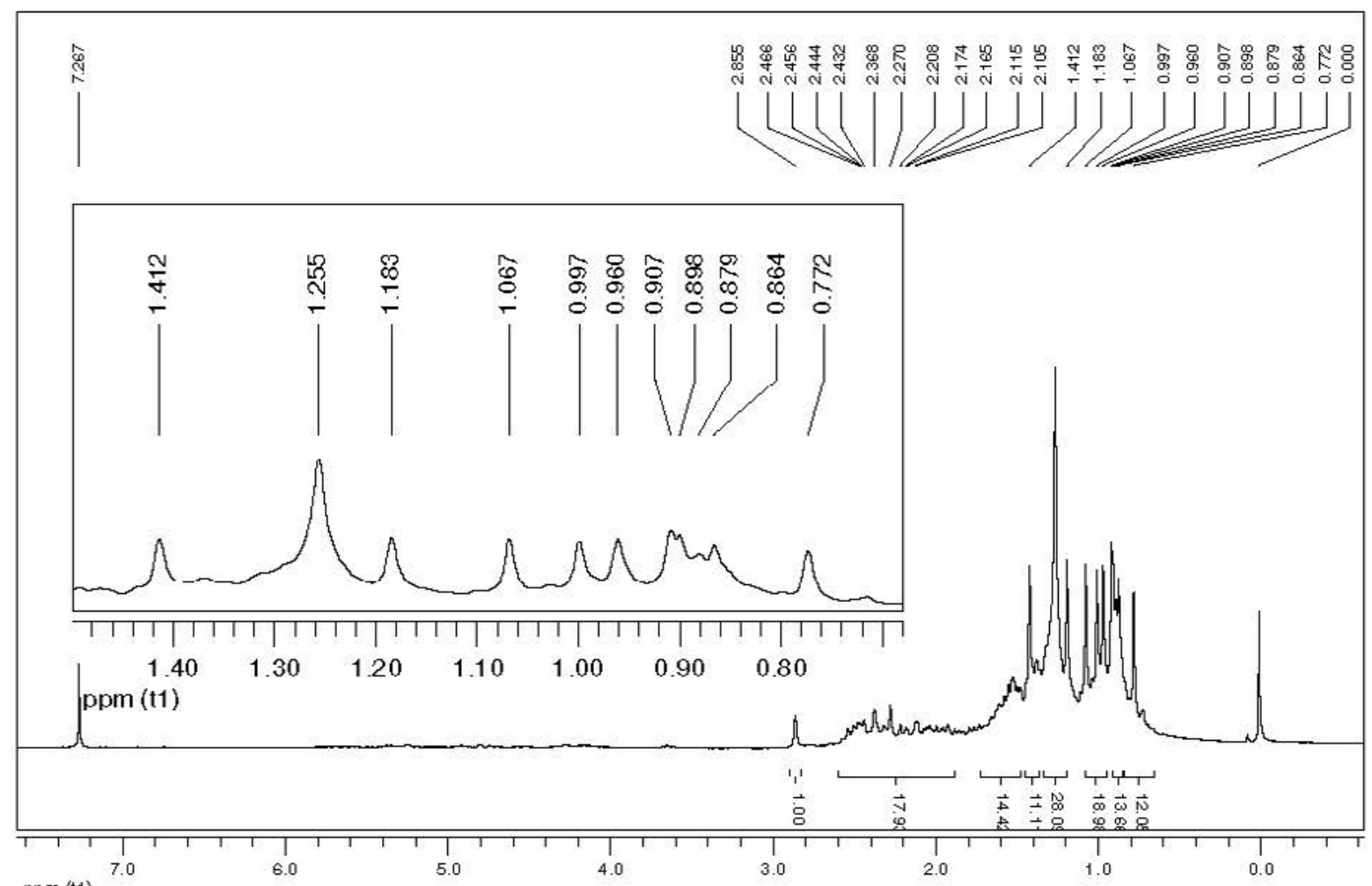

ppm (t-1)

Figure 10S. ${ }^{1} \mathrm{H}$ NMR spectrum of compound $3\left(200 \mathrm{MHz} \mathrm{CDCl}_{3}\right)$

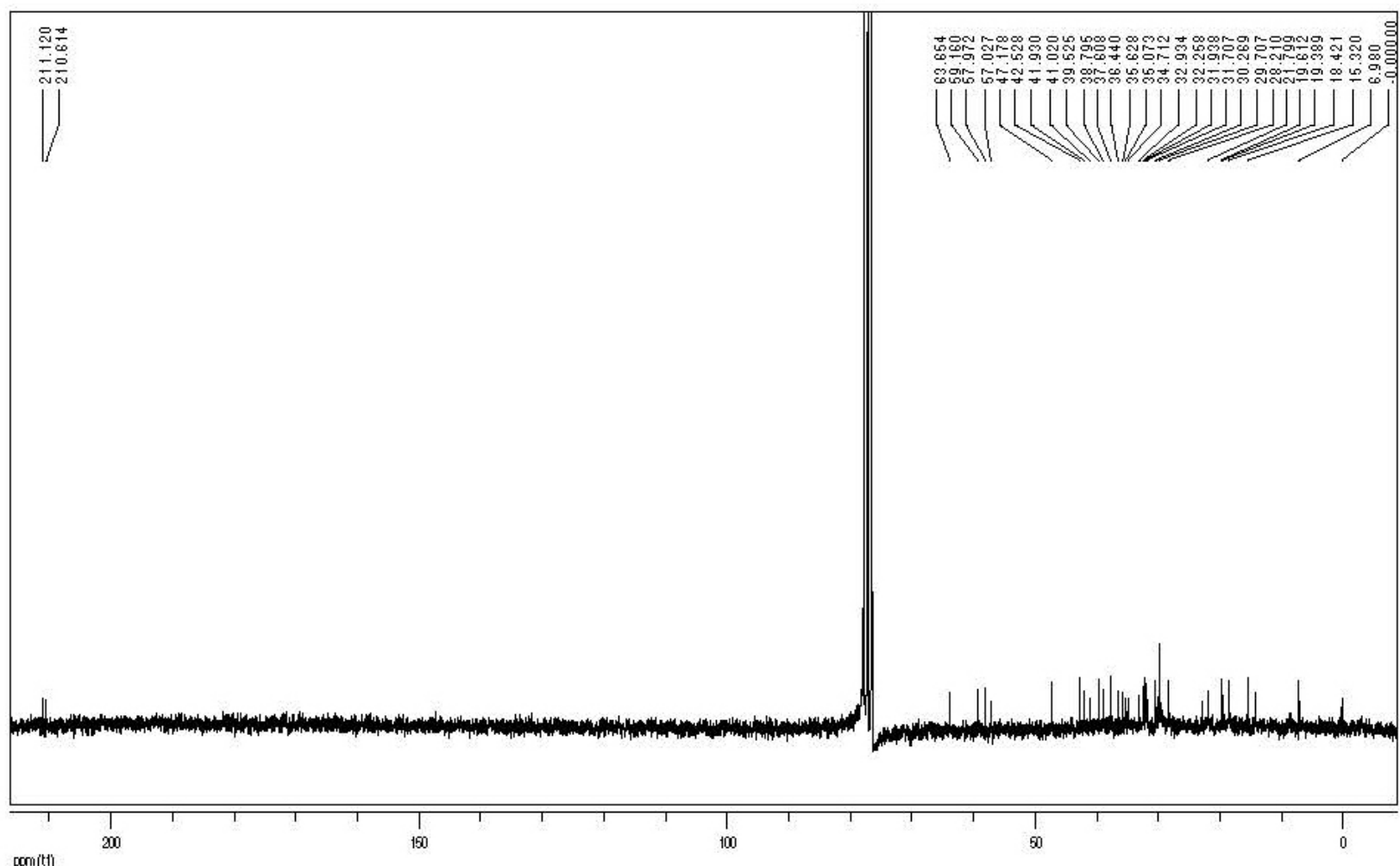

Figure 11S. ${ }^{13} \mathrm{C} \mathrm{NMR}$ spectrum of compound $3\left(50 \mathrm{MHz}, \mathrm{CDCl}_{3}\right)$ 


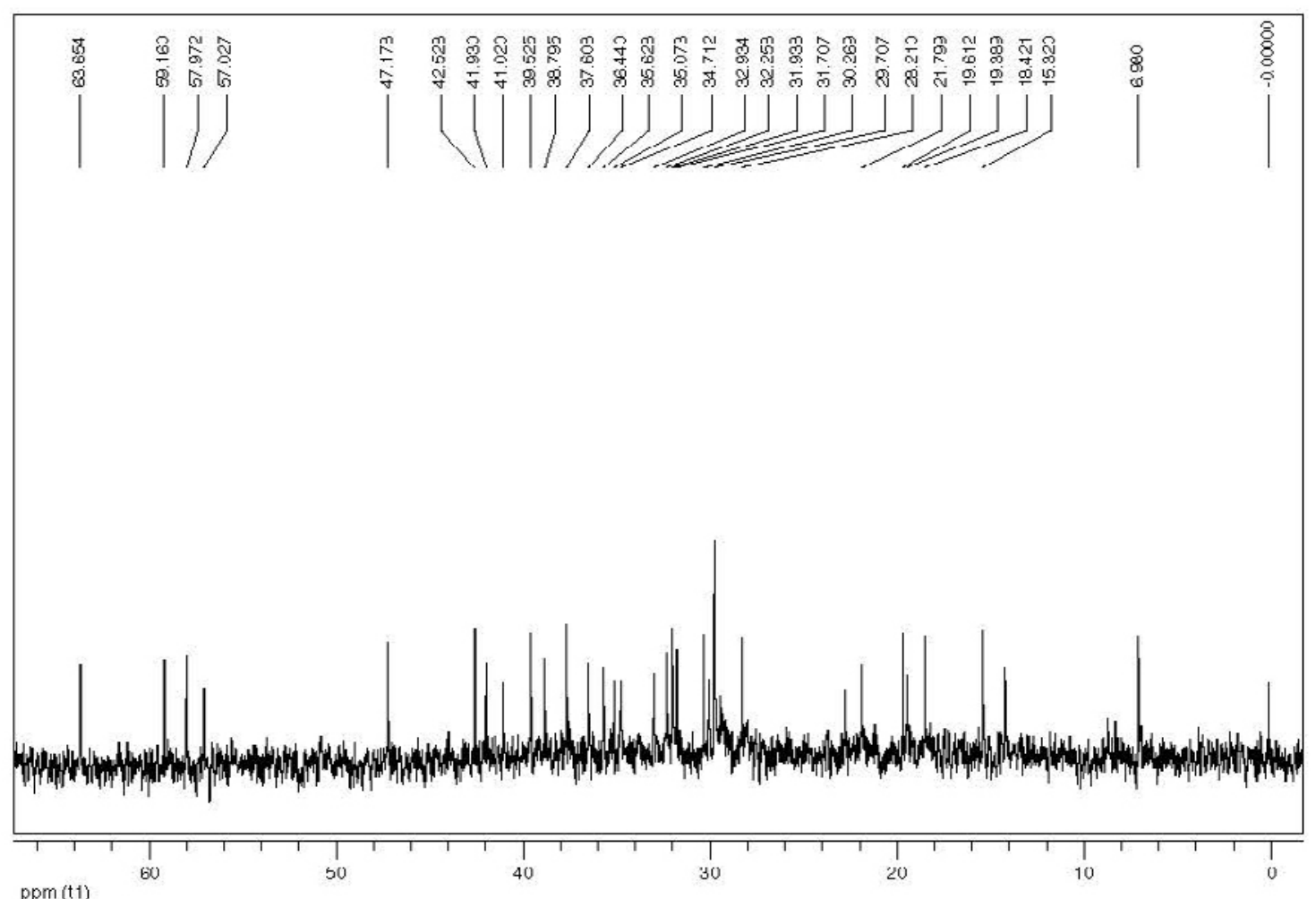

Figure 12S. ${ }^{13} \mathrm{C} \mathrm{NMR}$ spectrum of compound $3\left(50 \mathrm{MHz}, \mathrm{CDCl}_{3}\right)$

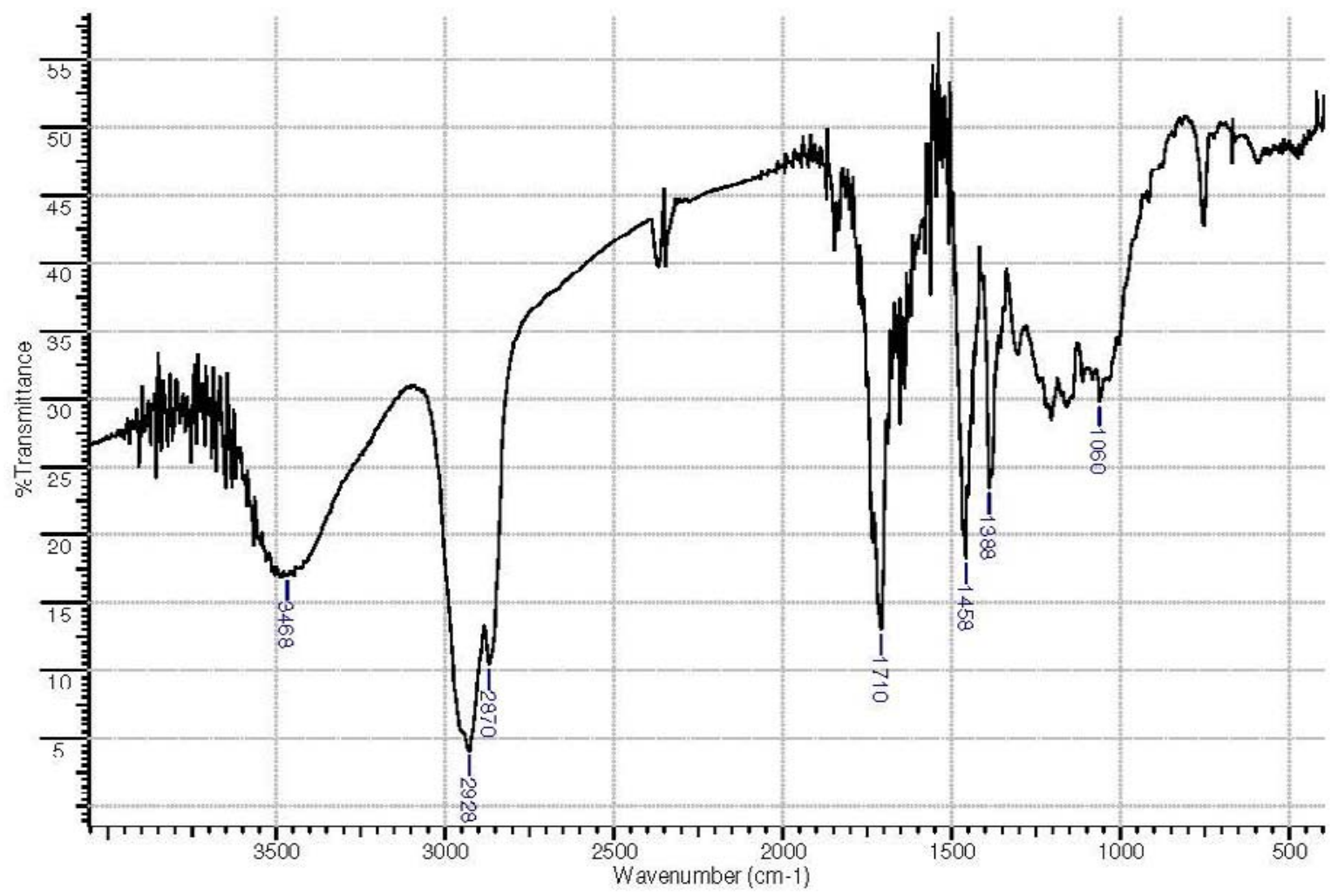

Figure 13S. IR spectrum of compound $4\left(\mathrm{KBr}, \mathrm{cm}^{-1}\right)$ 


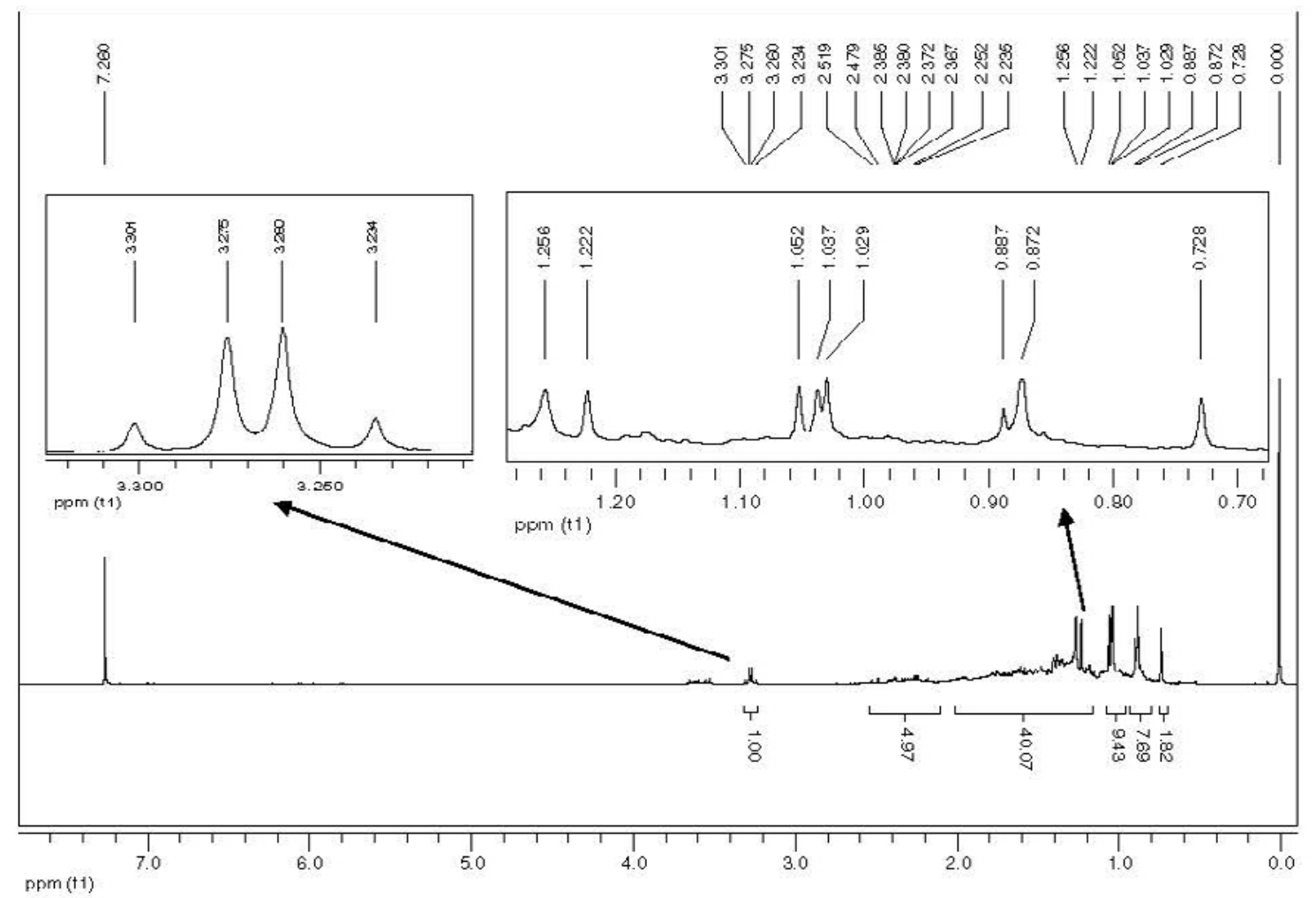

Figure 14S. ${ }^{1} \mathrm{H}$ NMR spectrum of compound $4\left(400 \mathrm{MHz}, \mathrm{CDCl}_{3}\right)$

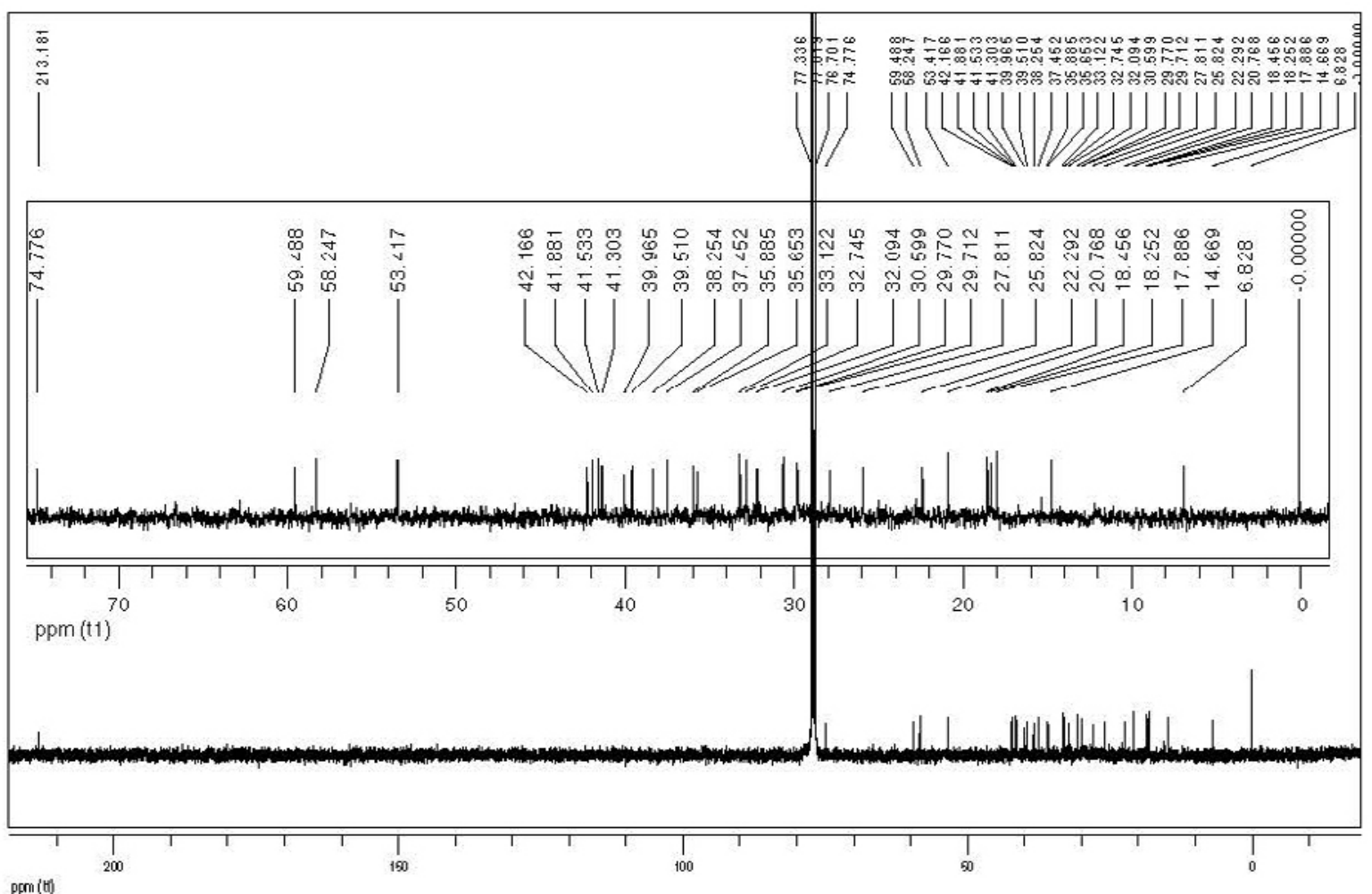

Figure 15S. ${ }^{13} \mathrm{C}$ NMR spectrum of compound $4\left(100 \mathrm{MHz}, \mathrm{CDCl}_{3}\right)$ 


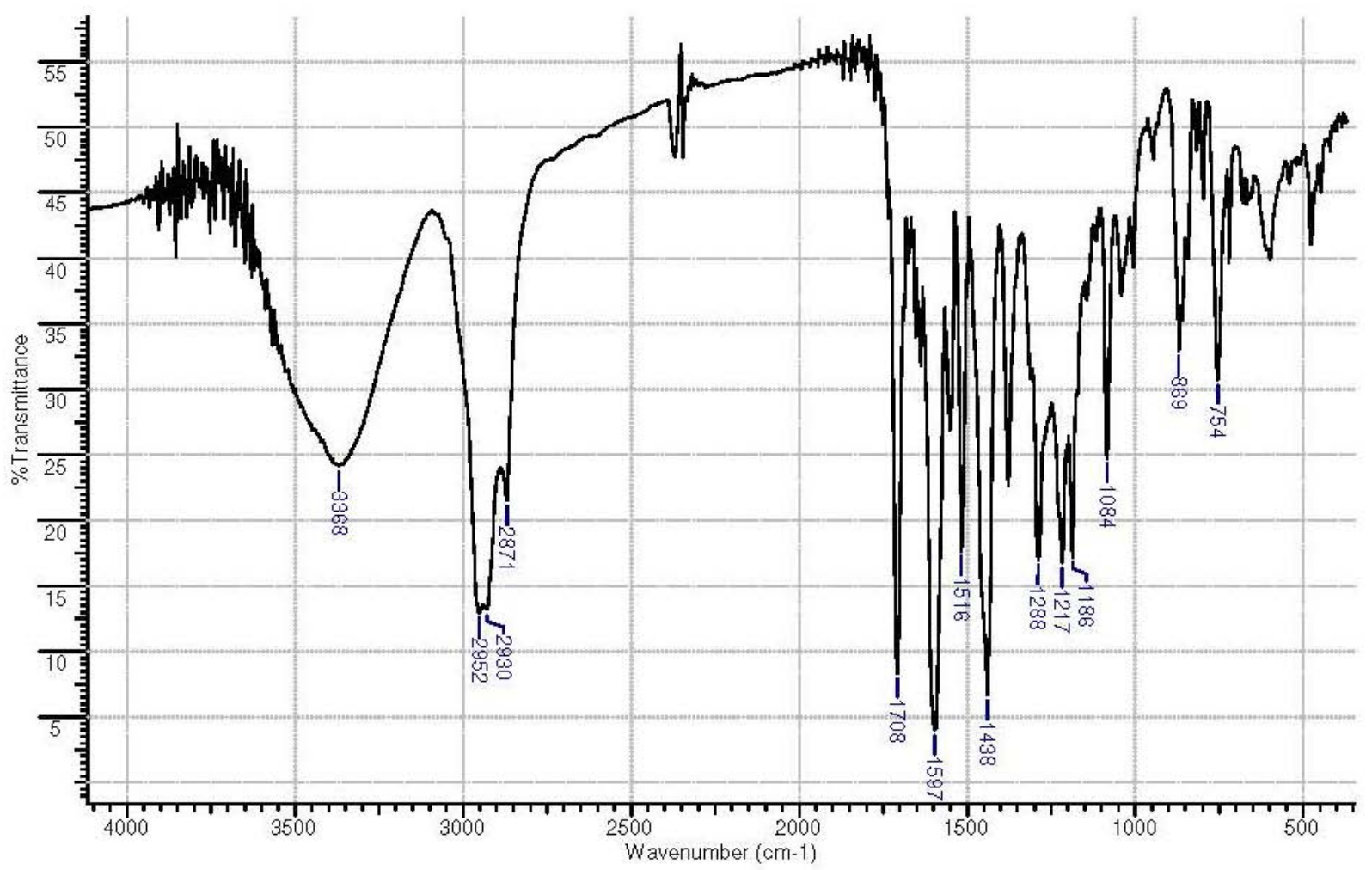

Figure 16S. IR spectrum of compound $5\left(\mathrm{KBr}, \mathrm{cm}^{-1}\right)$

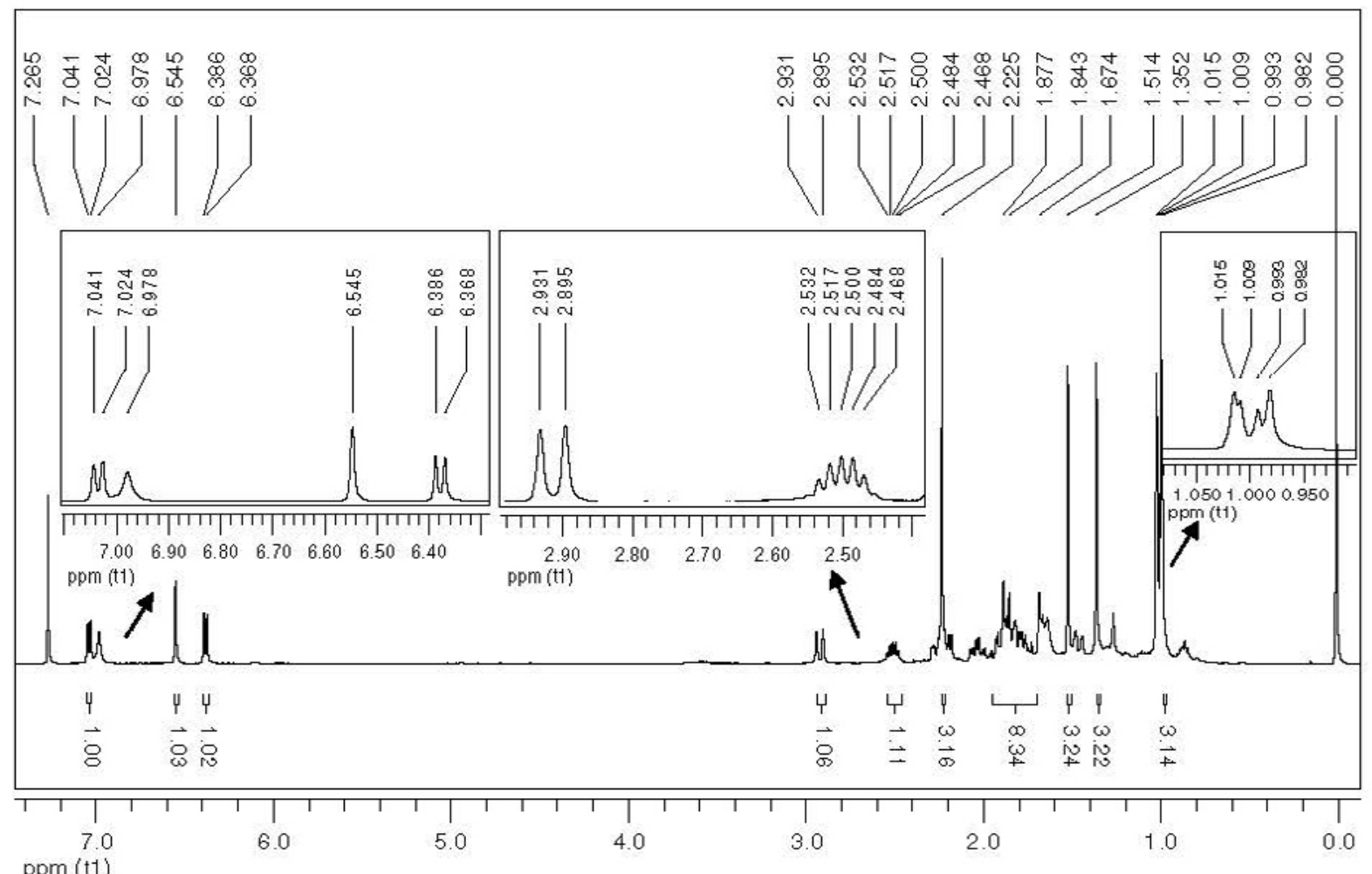

Figure 17S. ${ }^{1} \mathrm{H}$ NMR spectrum of compound $5\left(400 \mathrm{MHz}, \mathrm{CDCl}_{3}\right)$ 


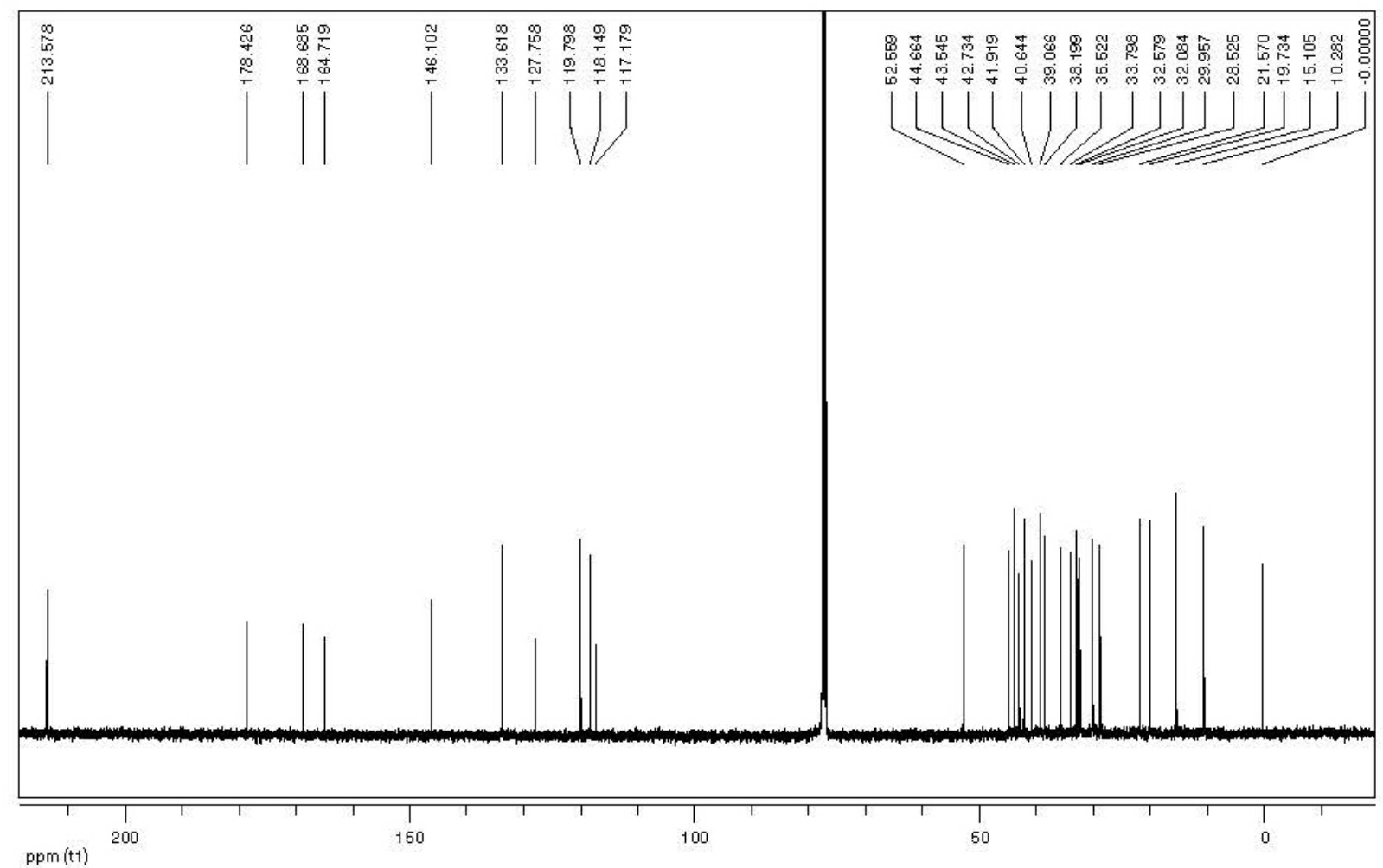

Figure 18S. ${ }^{13} \mathrm{C}$ NMR spectrum of compound $5\left(100 \mathrm{MHz}, \mathrm{CDCl}_{3}\right)$

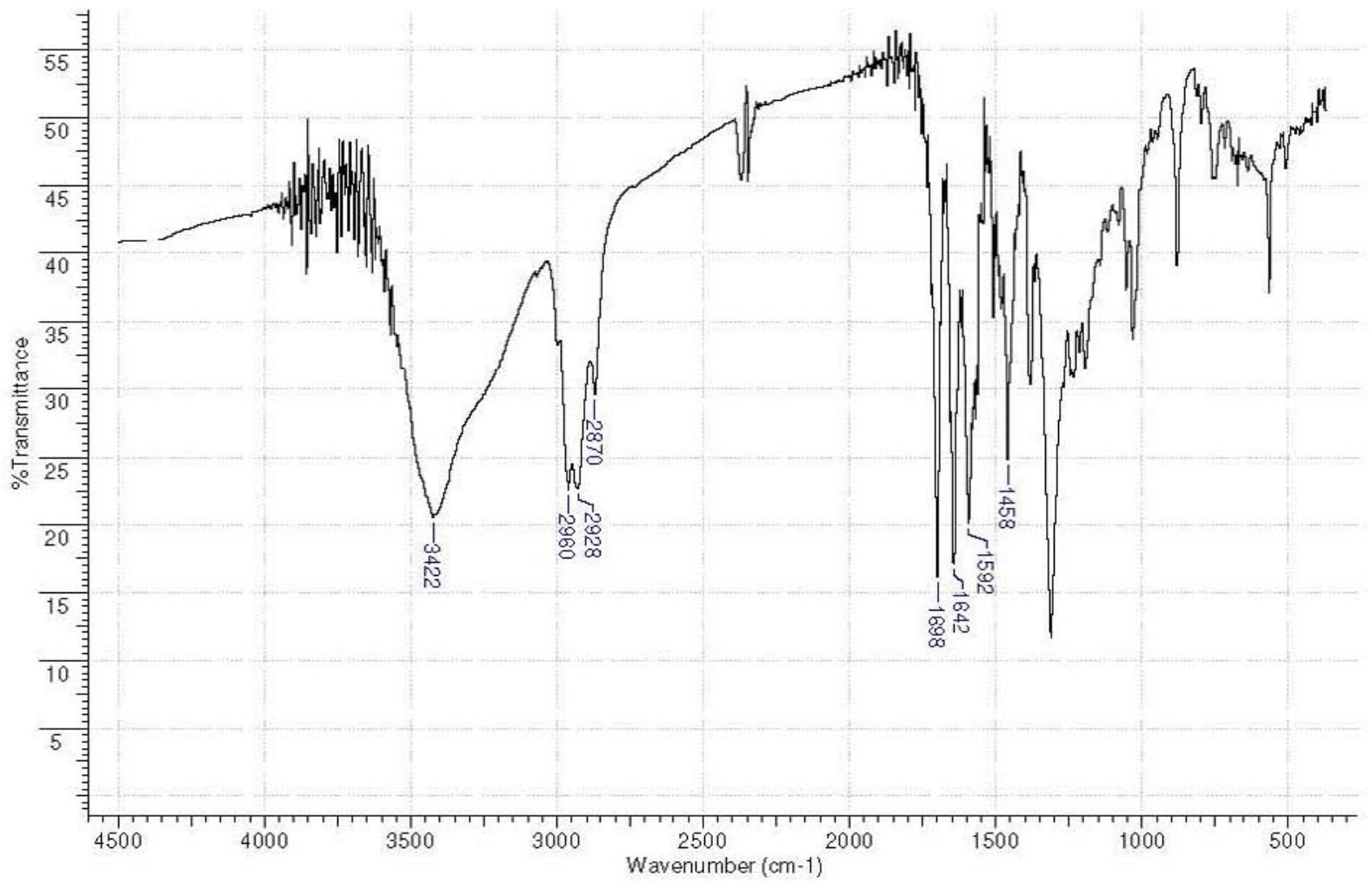

Figure 19S. IR spectrum of compound $6\left(\mathrm{KBr}, \mathrm{cm}^{-1}\right)$ 


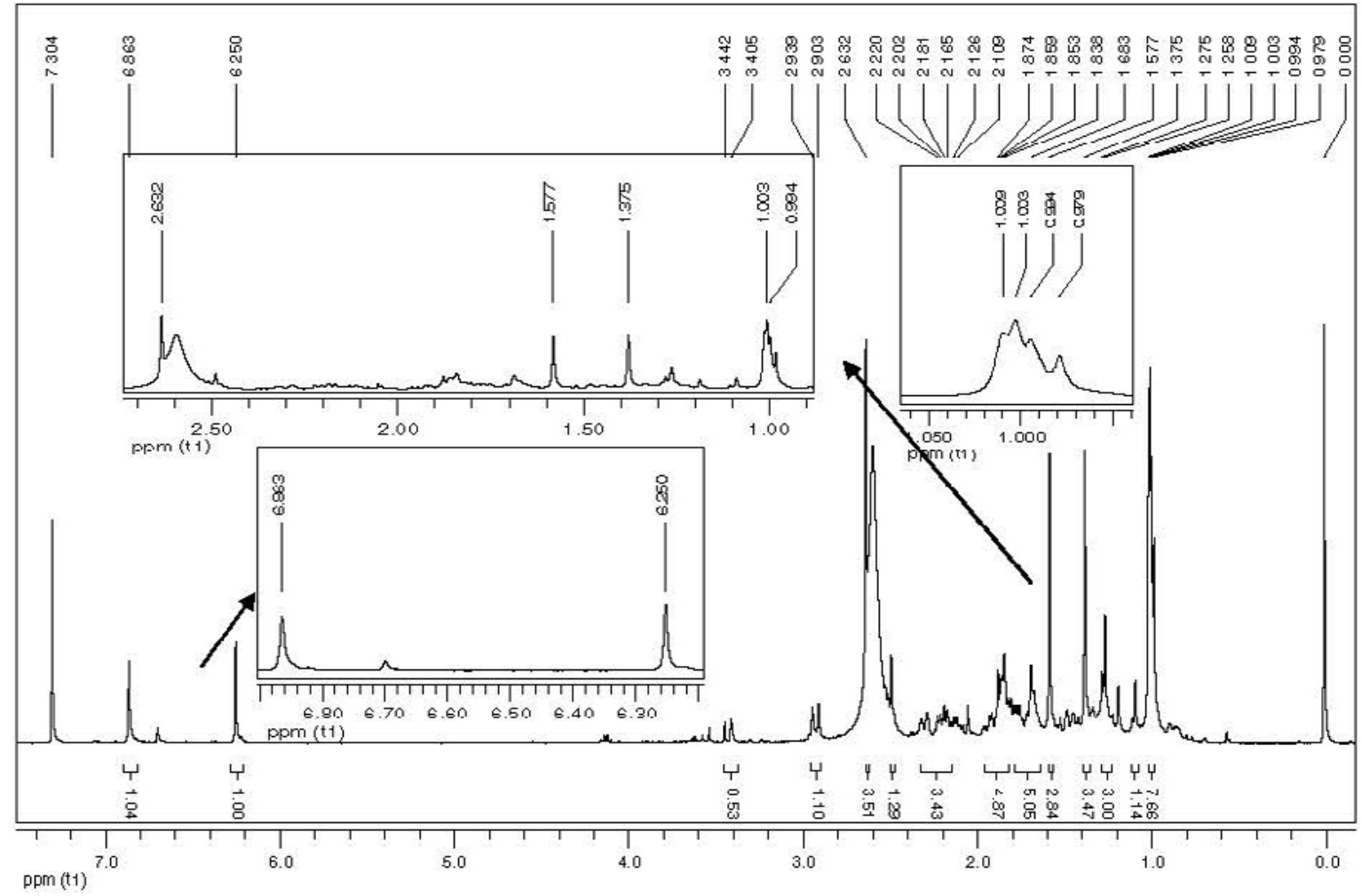

Figure 20S. ${ }^{1} \mathrm{H} N M R$ spectrum of compound $6\left(400 \mathrm{MHz}, \mathrm{CDCl}_{3}+\mathrm{CD}_{3} \mathrm{OD}\right)$

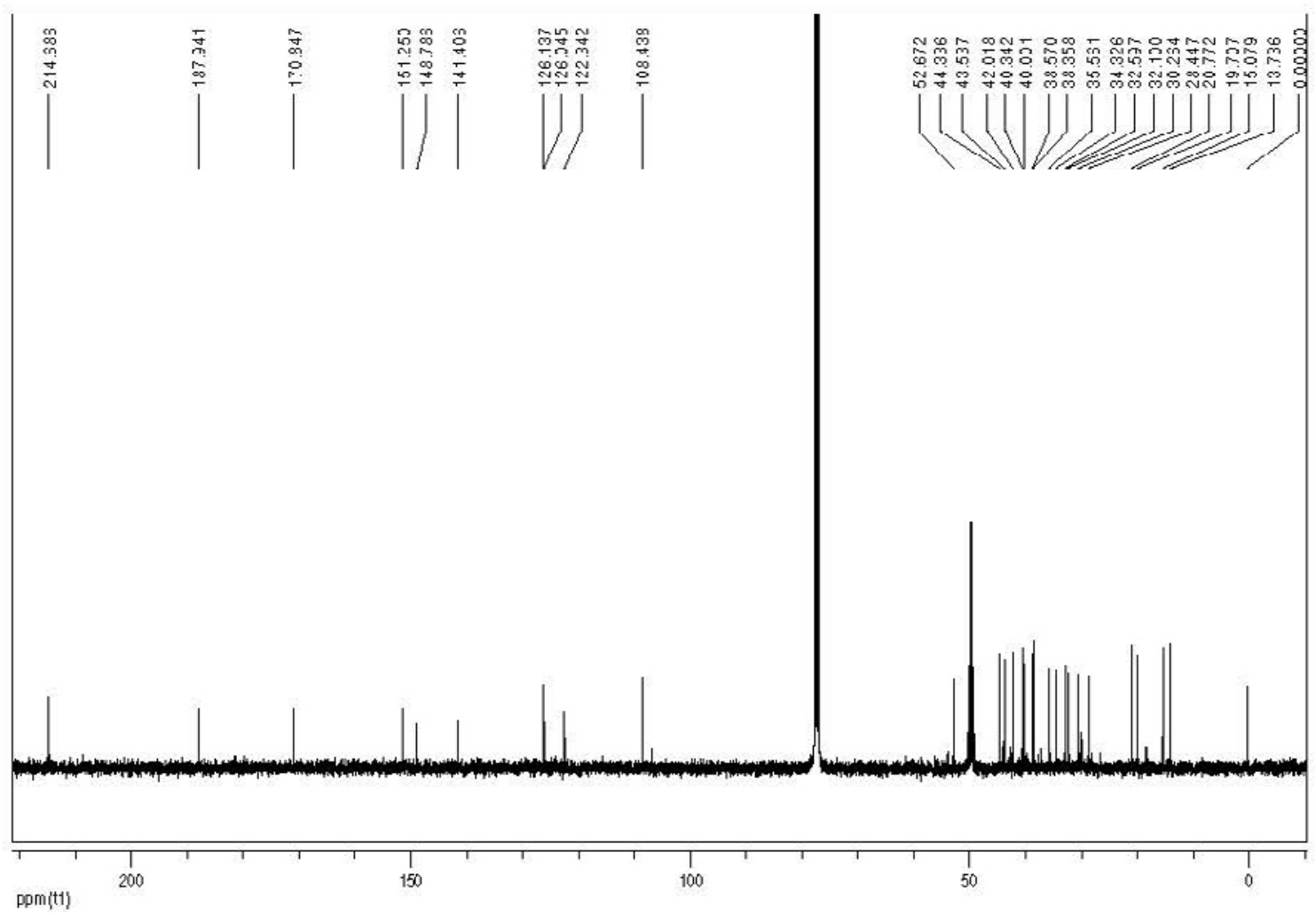

Figure 21S. ${ }^{13} \mathrm{C} \mathrm{NMR} \mathrm{spectrum} \mathrm{of} \mathrm{compound} 6\left(100 \mathrm{MHz}, \mathrm{CDCl}_{3}+\mathrm{CD}_{3} \mathrm{OD}\right)$ 
Table 1S. Comparison of ${ }^{13} \mathrm{C}$ NMR data of compound 1 with literature for $11 \alpha$-hydroxylup-20(29)-en-3-one

\begin{tabular}{|c|c|c|c|}
\hline $\mathrm{N}^{\circ}$ & Type of carbon & $\delta_{\mathrm{C}}$ of compound $\mathbf{1}$ & $\delta_{\mathrm{C}}$ ref. 22 \\
\hline 1 & $\mathrm{CH}_{2}$ & 42.09 & 42.07 \\
\hline 2 & $\mathrm{CH}_{2}$ & 34.23 & 34.21 \\
\hline 3 & $\mathrm{C}=\mathrm{O}$ & 218.78 & 218.84 \\
\hline 4 & $\mathrm{C}$ & 47.63 & 47.63 \\
\hline 5 & $\mathrm{CH}$ & 54.78 & 54.76 \\
\hline 6 & $\mathrm{CH}_{2}$ & 19.66 & 19.64 \\
\hline 7 & $\mathrm{CH}_{2}$ & 34.27 & 34.27 \\
\hline 8 & $\mathrm{C}$ & 42.63 & 42.41 \\
\hline 9 & $\mathrm{CH}$ & 54.90 & 54.87 \\
\hline 10 & $\mathrm{C}$ & 38.22 & 38.20 \\
\hline 11 & $\mathrm{CHOH}$ & 70.50 & 70.49 \\
\hline 12 & $\mathrm{CH}_{2}$ & 37.48 & 37.44 \\
\hline 13 & $\mathrm{CH}$ & 37.19 & 37.17 \\
\hline 14 & $\mathrm{C}$ & 42.42 & 42.16 \\
\hline 15 & $\mathrm{CH}_{2}$ & 27.43 & 27.41 \\
\hline 16 & $\mathrm{CH}_{2}$ & 35.42 & 35.40 \\
\hline 17 & $\mathrm{C}$ & 43.06 & 43.05 \\
\hline 18 & $\mathrm{CH}$ & 47.65 & 47.63 \\
\hline 19 & $\mathrm{CH}$ & 47.72 & 47.70 \\
\hline 20 & $\mathrm{C}$ & 150.22 & 150.20 \\
\hline 21 & $\mathrm{CH}_{2}$ & 29.80 & 29.78 \\
\hline 22 & $\mathrm{CH}_{2}$ & 39.82 & 39.80 \\
\hline 23 & $\mathrm{CH}_{3}$ & 27.47 & 27.46 \\
\hline 24 & $\mathrm{CH}_{3}$ & 20.78 & 20.77 \\
\hline 25 & $\mathrm{CH}_{3}$ & 16.70 & 16.71 \\
\hline 26 & $\mathrm{CH}_{3}$ & 16.87 & 16.86 \\
\hline 27 & $\mathrm{CH}_{3}$ & 14.43 & 14.42 \\
\hline 28 & $\mathrm{CH}_{3}$ & 18.09 & 18.08 \\
\hline 29 & $=\mathrm{CH}_{2}$ & 109.95 & 109.95 \\
\hline 30 & $\mathrm{CH}_{3}$ & 19.38 & 19.37 \\
\hline
\end{tabular}

Table 2S. Comparison of ${ }^{13} \mathrm{C}$ NMR data of compound 2 with literature for $3 \beta, 11 \alpha$-hydroxylup-20(29)-en-3-one

\begin{tabular}{|c|c|c|c|}
\hline $\mathrm{N}^{\circ}$ & Type of carbon & $\delta_{\mathrm{C}}$ of compound $\mathbf{2}$ & $\delta_{\mathrm{C}}$ ref. 21 \\
\hline 1 & $\mathrm{CH}_{2}$ & 39.83 & 39.00 \\
\hline 2 & $\mathrm{CH}_{2}$ & 27.41 & 27.50 \\
\hline 3 & $\mathrm{CH}$ & 78.57 & 78.60 \\
\hline 4 & $\mathrm{C}$ & 39.38 & 39.40 \\
\hline 5 & $\mathrm{CH}$ & 55.52 & 55.60 \\
\hline 6 & $\mathrm{CH}_{2}$ & 18.10 & 18.10 \\
\hline 7 & $\mathrm{CH}_{2}$ & 35.26 & 35.30 \\
\hline 8 & $\mathrm{C}$ & 42.54 & 41.10 \\
\hline 9 & $\mathrm{CH}$ & 55.65 & 55.70 \\
\hline 10 & $\mathrm{C}$ & 38.97 & 37.70 \\
\hline 11 & $\mathrm{CH}$ & 70.52 & 70.50 \\
\hline 12 & $\mathrm{CH}_{2}$ & 27.66 & 27.70 \\
\hline 13 & $\mathrm{CH}$ & 37.02 & 37.70 \\
\hline 14 & $\mathrm{C}$ & 42.60 & 42.60 \\
\hline 15 & $\mathrm{CH}_{2}$ & 27.41 & 27.50 \\
\hline 16 & $\mathrm{CH}_{2}$ & 35.47 & 35.50 \\
\hline 17 & $\mathrm{C}$ & 43.02 & 43.00 \\
\hline 18 & $\mathrm{CH}$ & 47.72 & 47.70 \\
\hline 19 & $\mathrm{CH}$ & 47.72 & 47.70 \\
\hline 20 & $\mathrm{C}$ & 150.26 & 150.20 \\
\hline 21 & $\mathrm{CH}_{2}$ & 29.78 & 29.90 \\
\hline 22 & $\mathrm{CH}_{2}$ & 41.03 & 39.90 \\
\hline 23 & $\mathrm{CH}_{3}$ & 28.27 & 28.30 \\
\hline 24 & $\mathrm{CH}_{3}$ & 15.53 & 15.60 \\
\hline 25 & $\mathrm{CH}_{3}$ & 16.39 & 16.10 \\
\hline 26 & $\mathrm{CH}_{3}$ & 17.23 & 17.30 \\
\hline 27 & $\mathrm{CH}_{3}$ & 14.51 & 14.50 \\
\hline 28 & $\mathrm{CH}_{3}$ & 18.07 & 18.10 \\
\hline 29 & $\mathrm{CH}_{2}$ & 109.91 & 109.80 \\
\hline 30 & $\mathrm{CH}_{3}$ & 19.35 & 19.40 \\
\hline
\end{tabular}


Table 3S. Comparison of ${ }^{13} \mathrm{C}$ NMR data of compound $\mathbf{3}$ with literature for 3,7-dioxo-friedelane

\begin{tabular}{|c|c|c|c|}
\hline $\mathrm{N}^{\mathrm{o}}$ & Type of carbon & $\delta_{\mathrm{C}}$ of compound $\mathbf{3}$ & $\delta_{C}$ ref. 21 \\
\hline 1 & $\mathrm{CH}_{2}$ & 21.80 & 21.60 \\
\hline 2 & $\mathrm{CH}_{2}$ & 41.02 & 40.80 \\
\hline 3 & $\mathrm{C}=\mathrm{O}$ & 211.12 & 210.60 \\
\hline 4 & $\mathrm{CH}$ & 57.97 & 57.80 \\
\hline 5 & $\mathrm{C}$ & 47.18 & 47.00 \\
\hline 6 & $\mathrm{CH}_{2}$ & 57.03 & 56.90 \\
\hline 7 & $\mathrm{C}=\mathrm{O}$ & 210.61 & 210.20 \\
\hline 8 & $\mathrm{CH}$ & 63.65 & 63.40 \\
\hline 9 & $\mathrm{C}$ & 42.53 & 42.40 \\
\hline 10 & $\mathrm{CH}$ & 59.16 & 59.00 \\
\hline 11 & $\mathrm{CH}_{2}$ & 35.63 & 35.50 \\
\hline 12 & $\mathrm{CH}_{2}$ & 29.71 & 29.80 \\
\hline 13 & $\mathrm{C}$ & 39.53 & 39.40 \\
\hline 14 & $\mathrm{C}$ & 37.61 & 37.50 \\
\hline 15 & $\mathrm{CH}_{2}$ & 31.94 & 31.60 \\
\hline 16 & $\mathrm{CH}_{2}$ & 36.44 & 36.30 \\
\hline 17 & $\mathrm{C}$ & 30.27 & 30.10 \\
\hline 18 & $\mathrm{CH}$ & 41.93 & 41.80 \\
\hline 19 & $\mathrm{CH}_{2}$ & 35.07 & 34.90 \\
\hline 20 & $\mathrm{C}$ & 28.21 & 28.00 \\
\hline 21 & $\mathrm{CH}_{2}$ & 32.93 & 32.80 \\
\hline 22 & $\mathrm{CH}_{2}$ & 38.80 & 38.60 \\
\hline 23 & $\mathrm{CH}_{3}$ & 6.98 & 6.80 \\
\hline 24 & $\mathrm{CH}_{3}$ & 15.32 & 15.10 \\
\hline 25 & $\mathrm{CH}_{3}$ & 18.42 & 18.20 \\
\hline 26 & $\mathrm{CH}_{3}$ & 19.39 & 19.20 \\
\hline 27 & $\mathrm{CH}_{3}$ & 19.61 & 19.40 \\
\hline 28 & $\mathrm{CH}_{3}$ & 32.26 & 32.10 \\
\hline 29 & $\mathrm{CH}_{3}$ & 31.71 & 31.80 \\
\hline 30 & $\mathrm{CH}_{3}$ & 34.71 & 34.60 \\
\hline
\end{tabular}

Table 4S. Comparison of ${ }^{13} \mathrm{C}$ NMR data of compound 4 with literature for 3-oxo-29-hydroxyfriedelane

\begin{tabular}{|c|c|c|c|}
\hline $\mathrm{N}^{\circ}$ & Type of carbon & $\delta_{\mathrm{C}}$ of compound 4 & $\delta_{\mathrm{C}}$ ref. 21 \\
\hline 1 & $\mathrm{CH}_{2}$ & 22.29 & 22.30 \\
\hline 2 & $\mathrm{CH}_{2}$ & 41.53 & 41.60 \\
\hline 3 & $\mathrm{C}$ & 213.18 & 212.20 \\
\hline 4 & $\mathrm{CH}$ & 58.25 & 58.30 \\
\hline 5 & $\mathrm{C}$ & 42.17 & 42.20 \\
\hline 6 & $\mathrm{CH}_{2}$ & 41.30 & 41.40 \\
\hline 7 & $\mathrm{CH}_{2}$ & 18.25 & 18.30 \\
\hline 8 & $\mathrm{CH}$ & 53.42 & 53.50 \\
\hline 9 & $\mathrm{C}$ & 37.45 & 37.50 \\
\hline 10 & $\mathrm{CH}$ & 59.49 & 59.60 \\
\hline 11 & $\mathrm{CH}_{2}$ & 35.65 & 35.70 \\
\hline 12 & $\mathrm{CH}_{2}$ & 29.71 & 29.80 \\
\hline 13 & $\mathrm{C}$ & 39.97 & 40.00 \\
\hline 14 & $\mathrm{CH}$ & 38.25 & 38.30 \\
\hline 15 & $\mathrm{CH}_{2}$ & 32.75 & 32.80 \\
\hline 16 & $\mathrm{CH}_{2}$ & 35.89 & 36.00 \\
\hline 17 & $\mathrm{C}$ & 29.77 & 29.80 \\
\hline 18 & $\mathrm{CH}$ & 41.88 & 42.00 \\
\hline 19 & $\mathrm{CH}_{2}$ & 30.60 & 30.60 \\
\hline 20 & $\mathrm{C}$ & 33.12 & 33.20 \\
\hline 21 & $\mathrm{CH}_{2}$ & 27.81 & 27.90 \\
\hline 22 & $\mathrm{CH}_{2}$ & 39.51 & 39.60 \\
\hline 23 & $\mathrm{CH}_{3}$ & 6.83 & 6.80 \\
\hline 24 & $\mathrm{CH}_{3}$ & 14.67 & 14.70 \\
\hline 25 & $\mathrm{CH}_{3}$ & 17.89 & 17.90 \\
\hline 26 & $\mathrm{CH}_{3}$ & 18.46 & 18.40 \\
\hline 27 & $\mathrm{CH}_{3}$ & 20.77 & 20.80 \\
\hline 28 & $\mathrm{CH}_{3}$ & 32.09 & 32.10 \\
\hline 29 & $\mathrm{CH}_{2}$ & 74.78 & 74.80 \\
\hline 30 & $\mathrm{CH}_{3}$ & 25.82 & 25.90 \\
\hline
\end{tabular}


Table 5S. Comparison of ${ }^{13} \mathrm{C}$ NMR data of compound $\mathbf{5}$ with literature for tingenone

\begin{tabular}{|c|c|c|c|}
\hline $\mathrm{N}^{\mathrm{o}}$ & Type of carbon & $\delta_{\mathrm{C}}$ of compound $\mathbf{5}$ & $\delta_{\mathrm{C}}$ ref. 23 \\
\hline 1 & $\mathrm{CH}$ & 119.80 & 119.80 \\
\hline 2 & $\mathrm{C}$ & 178.43 & 178.40 \\
\hline 3 & $\mathrm{C}$ & 146.10 & 146.00 \\
\hline 4 & $\mathrm{C}$ & 117.18 & 117.10 \\
\hline 5 & $\mathrm{C}$ & 127.76 & 127.70 \\
\hline 6 & $\mathrm{CH}$ & 133.62 & 133.60 \\
\hline 7 & $\mathrm{CH}$ & 118.15 & 118.10 \\
\hline 8 & $\mathrm{C}$ & 168.69 & 168.70 \\
\hline 9 & $\mathrm{C}$ & 42.73 & 42.70 \\
\hline 10 & $\mathrm{C}$ & 164.72 & 164.70 \\
\hline 11 & $\mathrm{CH}_{2}$ & 33.80 & 33.80 \\
\hline 12 & $\mathrm{CH}_{2}$ & 29.96 & 29.90 \\
\hline 13 & $\mathrm{C}$ & 40.64 & 40.60 \\
\hline 14 & $\mathrm{C}$ & 44.66 & 44.60 \\
\hline 15 & $\mathrm{CH}_{2}$ & 28.53 & 28.50 \\
\hline 16 & $\mathrm{CH}_{2}$ & 35.52 & 35.50 \\
\hline 17 & $\mathrm{C}$ & 38.20 & 38.20 \\
\hline 18 & $\mathrm{CH}$ & 43.55 & 43.50 \\
\hline 19 & $\mathrm{CH}_{2}$ & 32.08 & 32.00 \\
\hline 20 & $\mathrm{CH}$ & 41.92 & 41.80 \\
\hline 21 & $\mathrm{C}$ & 213.58 & 213.60 \\
\hline 22 & $\mathrm{CH}_{2}$ & 52.56 & 52.50 \\
\hline 23 & $\mathrm{CH}_{3}$ & 10.28 & 10.20 \\
\hline 25 & $\mathrm{CH}_{3}$ & 39.07 & 39.00 \\
\hline 26 & $\mathrm{CH}_{3}$ & 21.57 & 21.50 \\
\hline 27 & $\mathrm{CH}_{3}$ & 19.73 & 19.70 \\
\hline 28 & $\mathrm{CH}_{3}$ & 32.58 & 32.50 \\
\hline 30 & $\mathrm{CH}_{3}$ & 15.11 & 15.10 \\
\hline
\end{tabular}

Table 6S. Comparison of ${ }^{13} \mathrm{C}$ NMR data of compound 6 with literature for 6-oxo-tingenol

\begin{tabular}{|c|c|c|c|}
\hline $\mathrm{N}^{\mathrm{o}}$ & Type of carbon & $\delta_{\mathrm{C}}$ of compound $\mathbf{6}$ & $\delta_{\mathrm{C}}$ ref. 24 \\
\hline 1 & $\mathrm{CH}$ & 108.44 & 108.19 \\
\hline 2 & $\mathrm{C}$ & 148.79 & 148.87 \\
\hline 3 & $\mathrm{C}$ & 141.41 & 141.42 \\
\hline 4 & $\mathrm{C}$ & 126.14 & 125.87 \\
\hline 5 & $\mathrm{C}$ & 122.34 & 121.71 \\
\hline 6 & $\mathrm{C}=\mathrm{O}$ & 187.94 & 187.90 \\
\hline 7 & $\mathrm{CH}$ & 126.05 & 125.53 \\
\hline 8 & $\mathrm{C}$ & 170.85 & 171.02 \\
\hline 9 & $\mathrm{C}$ & 40.34 & 40.07 \\
\hline 10 & $\mathrm{C}$ & 151.25 & 150.99 \\
\hline 11 & $\mathrm{CH}_{2}$ & 35.56 & 35.23 \\
\hline 12 & $\mathrm{CH}_{2}$ & 30.26 & 29.93 \\
\hline 13 & $\mathrm{C}$ & 40.00 & 39.75 \\
\hline 14 & $\mathrm{C}$ & 44.34 & 44.02 \\
\hline 15 & $\mathrm{CH}_{2}$ & 28.45 & 28.14 \\
\hline 16 & $\mathrm{CH}_{2}$ & 32.10 & 31.81 \\
\hline 17 & $\mathrm{C}$ & 38.36 & 38.18 \\
\hline 18 & $\mathrm{CH}$ & 43.54 & 43.23 \\
\hline 19 & $\mathrm{CH}_{2}$ & 34.33 & 33.99 \\
\hline 20 & $\mathrm{CH}$ & 42.02 & 41.74 \\
\hline 21 & $\mathrm{C}=\mathrm{O}$ & 214.69 & 215.08 \\
\hline 22 & $\mathrm{CH}_{2}$ & 52.67 & 52.35 \\
\hline 23 & $\mathrm{CH}_{3}$ & 13.74 & 13.23 \\
\hline 25 & $\mathrm{CH}_{3}$ & 38.57 & 38.09 \\
\hline 26 & $\mathrm{CH}_{3}$ & 20.77 & 20.40 \\
\hline 27 & $\mathrm{CH}_{3}$ & 19.71 & 19.30 \\
\hline 28 & $\mathrm{CH}_{3}$ & 32.60 & 32.12 \\
\hline 30 & $\mathrm{CH}_{3}$ & 15.08 & 14.55 \\
\hline
\end{tabular}

